\title{
The mental template in handaxe manufacture: new insights into Acheulean lithic technological behavior at Boxgrove, Sussex, UK.
}

\author{
Paula García-Medrano ${ }^{1,5}$, Andreu Ollée,3, Nick Ashton', Mark B. Roberts ${ }^{4}$ \\ 1 Dept. Britain, Europe \& Prehistory. British Museum. Franks House, 56 Orsman Road, London, N1 5QJ, UK \\ 2 Institut Català de Paleoecologia Humana i Evolució Social (IPHES), Zona educacional 4, Campus Sescelades \\ URV (Edifici W3), 43007 Tarragona, Spain \\ 3 Àrea de Prehistòria, Universitat Rovira i Virgili (URV), Fac. Lletres, Av. Catalunya, 35, 43002 Tarragona, Spain \\ ${ }^{4}$ Institute of Archaeology, UCL, 31-34 Gordon Square, London WC1H OPY, UK \\ ${ }^{5}$ Corresponding author, pgarciamedrano@gmail.com Tlf. +34 620957489
}

\begin{abstract}
The morphological variability of Large Cutting Tools (LCT) during the Middle Pleistocene has been traditionally associated with two main variables: raw material constraints and reduction intensity. Boxgrove - c.500ka - is one of the most informative sites at which to analyze shaping strategies and handaxe morphological variability in the European Middle Pleistocene, because of the large number of finished handaxes, and the presence of complete operational chains. We focused on the entire handaxe and rough-out sample from Boxgrove-Q1/B with the aim of assessing the role of raw material characteristics - size, form, and homogeneity of nodules - in the shaping process, and to ascertain if they represent real constraints in the production of handaxes. Additionally, given the large number of handaxes and the intensity of the thinning work at Boxgrove, we also aimed to determine if reduction intensity affected the final shape to the degree that some authors have previously postulated. The methodology combines traditional technological descriptions, metrical analysis, and experimental reproduction of shaping processes together with geometric morphometry and PCA. The conclusions we draw are that the Q1/B handaxe knapping strategies were flexible and adapted to the characteristics of the blanks. These characteristics affected the reduction strategy but there is no clear relationship between initial nodule or blank morphology and final handaxe shape. Throughout the experiments, we explored the capacity to solve problems arising from reduction accidents, which led to re-configuring the knapping strategy to achieve the predetermined "mental template". Furthermore, no substantial morphological differences related to reduction intensity were noticed with the Q1/B handaxes. Systematic re-sharpening as the cause of shape variation seems highly unlikely, perhaps related to the short use-life of the Boxgrove-Q1/B handaxes. Preferred forms constitute part of a broader pattern emerging for specific handaxe types at different times during the British Acheulean. The patterns have tentatively been interpreted as the result of changing environments and the movement of hominin populations.
\end{abstract}

Keywords: Acheulean, handaxe, shaping strategies, morphometry

\section{Acknowledgements}

We are deeply grateful to the Boxgrove team at the Institute of Archaeology, UCL, and the British Museum for giving us access to the archaeological material and all the facilities during the process. We are grateful to the knappers: J.M. Vergès, M. Guardiola and J. Guiu, plus one of the authors (A.O.). P.G.M. benefited from a pre-doctoral research grant from the Fundación Siglo para las Artes en Castilla y León, and from two pre-doctoral mobility grants to London by University of Burgos, supported by Dr. Carlos Díez. The experimental session was supported by the Catalan AGAUR project 2008-PBR-00033. This work was developed within the frame of the projects SGR2017-10402014-899 (AGAUR), 2014/2015/2016PFRURV-B2-17 (URV) and CGL2015-65387-C3-1-P (MINECO/FEDER), and inside the CERCA Programme / Generalitat de Catalunya. P.G.M. has been granted a fellowship from the 
European Union's Horizon 2020 research and innovation programme under the Marie Sklodowska-Curie grant agreement N. 748316.

\section{Introduction}

The beginning of the Acheulean around 1.7-1.5 Ma and the production of new tools handaxes - was a revolutionary technological development, marking a break with the previous technology based on cores and flakes (Gowlett 2006). In this new techno-complex, the knapping sequence was devoted to producing a standardized residual form, i.e a handaxe (Roche 2005; Gowlett 2006). The handaxe, as the first bifacially shaped tool, is considered the best reflection of advanced human cognition at this time, demonstrating the ability of hominins to follow a mental template and creating a tear-drop shape with bilateral symmetry (Gowlett 1986; Wynn 2002; Goren-Inbar 2011; Stout 2011). It is assumed that the versatility and effectiveness of these large tools resulted in their persistence over more than one and a half million years over a vast geographical area, from Africa to Britain and from the Iberian Peninsula to China, involving several hominin species (Clark 1994; Wynn 1995; Gowlett 2011; Moncel et al. in press). However, despite the apparent stability of the Acheulean in terms of stone tool production, especially handaxes, understanding the variability within such a techno-complex and the relationship of the tool to the task performed, continue to be major research issues.

The term Large Cutting Tool (LCT) is a single heading for unifacially and bifacially knapped Acheulean tools of all types. It includes not only handaxes but cleavers, picks, and other heavy tools, which emphasizes the importance of the cutting edge as the tool's main raison d'être (Sharon 2007). The morphological variability documented within Middle Pleistocene LCTs has been deeply discussed and variously interpreted by different researchers. Differences in raw material and hence mechanical constraints have been regarded as the major factors influencing LCT morphological variability. Some authors have concluded that lithic raw material qualities, the characteristics of the original nodule or block, and the way they are adapted to the knapping strategies, were the main determining factors in stone tool morphology (Ashton and McNabb 1994; White 1995; White 1998a; Ashton and White 2003). It should be noted in this context that much of the debate surrounding the effects of raw material shape on LCT morphology has been derived from the study and experimentation on the production of handaxes from flint nodules (Stout et al. 2014). Nevertheless, other authors point out that raw material constraints did not significantly affect either the blank production process or large cutting tool shape and size variability (Sharon, 2008).

Other researchers have proposed that one of the most important determinants of shape and size variation in Acheulean handaxes is the degree of reduction to which they have been subjected (McPherron 1999; White 2006; Ashton 2008; Emery 2010; lovita and McPherron 2011). It has been argued that at the start of reduction, the morphology of the handaxes would have been dominated by pointed and thick forms; in the process of reduction, the morphology would have changed from pointed to thinner and more ovate forms. So the morphological differences in handaxes were a by-product of the reduction process. However, these authors have lacked an independent measure to calculate reduction intensity; recently, a measure to redress this omission has been proposed by Clarkson and Shipton (Clarkson 2013; Shipton et al. 2013; Shipton and Clarkson 2015 a,b): the Scar Density Index (SDI), defined as the number of flake scars (greater than $10 \mathrm{~mm}$ in maximum dimension) divided by the surface area.

Neither of these models of possible constraints considered some of the arguments related to cultural tradition (Roe 1968; Wenban-Smith et al. 2000; Wenban-Smith 2004). The longstanding arguments proposing cultural tradition as the prime influence saw the final morphological characteristics of handaxes reflecting the mental template of the knappers and 
raw material was selected according to the mental template. These authors argued that the selection of ovate and pointed forms was a conscious decision made by the knapper according to existing mental templates. So, it was contrary to the raw material hypothesis that pointed handaxes could not be transformed into ovates because of raw material limitations. Additionally, contrary to the reduction model, they showed the existence of refined and symmetrical pointed handaxes, showing intensive reduction (Wenban-Smith et al. 2000), obviating the concept of pointed=crude, ovate=refined. The notion of the mental template enables the exploration of cognitive skills - where such blanks were shaped to produce handaxes with similar morphologies. This has been considered as one of the two main innovations of the Acheulean, together with the production of large flakes (Isaac 1969, 1986), which entailed a new planning sequence, linked to the spatial notion of interval and the hierarchical organization of cognitive activities (Wynn 1989). Toth (1991) added a new innovation for the Acheulean: the temporal and spatial fragmentation of lithic reduction sequences (the planning of a geographical and sequential segregation of quarrying production and use), which has significant cognitive demands. In addition, handaxe shaping implies demands on the $x, y$ and $z$ functions of working memory (Stout 2015). All the inferred technical requirements of Acheulean flaking are consistent with the dramatic increase in brain size observed in early $H$. erectus (Antón 2003).

The debate concerning morphology also considered functional hypotheses (Crompton and Gowlett 1993; Gowlett and Crompton 1994; Gowlett 2006). Through study of the relative breadth and length of handaxes from Africa and Europe, Gowlett (2011) concluded that there was a preference for handaxes of greater length, which implied the existence of a sense of proportion among the Acheulean knappers, derived from a long period of social transmission through the search for technological success. In addition, research that has been grounded in anthropology has tended to explain handaxe morphological variability in terms of the influence of the individual knapper (Gamble 1999; Stout 2002; Petraglia 2006), axiomatically noting that the best knappers produce the more refined and symmetrical forms. Gender has also been considered a variable to influence handaxe variability. Kohn and Mithen (1999) and Mithen (2005) argued that males are presumed to have made highly symmetrical handaxes, with females responsible for less refined tools, although these interpretations have been intensively debated (Nowell and Lee Chang 2009; Spikins 2012).

The Boxgrove-Q1/B handaxe sample is one of the most significant assemblages available for study with a large set of finished handaxes and almost complete reduction sequences (Roberts and Parfitt 1999). A total set of 459 handaxes and rough-outs were recovered, of which 358 finished handaxes and 62 rough-outs were available for this study. The technological analysis has been complemented with an experimental programme devoted to solving specific technical questions that derived from archaeological lithic research, e.g. the middle stages in the shaping process and how these could affect the operative chain. The aim of this study is to define the technical characteristics of the Q1/B handaxes, analyze the shaping strategies and examine the final morphologies of the handaxes to explore the origin of their variability. Accordingly, variability is analyzed using the following research questions: 1) What role does the raw material play? 2) Does the type of blank influence handaxe morphology? 3) How is the reduction of volume managed through the knapping sequence? 4) Does the intense thinning work define the final tool's shape? 5) Can we identify a mental template, beyond the different constraints of the knapping process?

The Boxgrove-Q1/B record is characterized by a high level of shape standardization in spite of the use of blanks of different metrical characteristics and the high variability in shaping processes to generate handaxes. In addition, the intense final shaping (thinning works) are what contribute to the homogeneity of the sample. Nevertheless, systematic re-sharpening as the cause of shape variation seems highly unlikely, perhaps related to the short use-life of these handaxes. Preferred forms constitute part of a broader pattern emerging for specific 
handaxe types at different times during the British Acheulean. The patterns have tentatively been interpreted as the result of changing environments and the movement of hominin populations.

\section{The archaeological site of Boxgrove}

The geology at the site of Boxgrove consists of a sequence of Middle Pleistocene marine, freshwater and terrestrial sediments exposed in the former Eartham Quarry, Boxgrove, West Sussex, UK (Figure 1). Archaeology occurs in all the main sedimentary units in the sequence but is preserved in situ and in the greatest concentration within an intertidal and regressional deposit, the Slindon Silt Member (Units 4a-c). The units comprising this member were formed within a semi-enclosed marine embayment at the onset of marine regression (Barnes 1980; Roberts and Pope 2009, 2018).

Within open excavation area Q1/B (Figure 2), the conventional marine-terrestrial sequence recorded elsewhere in the quarry complex has been eroded and reworked by freshwater seeps and springs from the base of the relict chalk sea-cliff some $75-100 \mathrm{~m}$ to the north of the site (Table 1). The freshwater flow into this part of the bay became manifest after full marine regression, and resulted in the removal of Units $4 \mathrm{a}$ and $4 \mathrm{~b}$, the formation of channels across, and planation of, the surface of the marine sand (Unit 3). These events were coeval with the formation of a small lake or large waterhole, bounded to the south, west and east by the marine-terrestrial sequence and to the north by the cliff line (Figure 3a) (Holmes et al 2010). The lake has a mappable east-west dimension of $70 \mathrm{~m}$ at its southern shore but is thought to increase in diameter towards the north. The water body was gradually infilled with silty muds derived from the reworking of the surrounding Slindon Silt and a small but significant amount of highly calcareous material carried by the springwater discharge (Figures 3a,b). The deposits of the lake from the channels (Unit 3c) up to the highly calcareous sediments (Unit 4d) are partly overlain on the drier margins of the lake shore by Unit 5a an organic freshwater deposit laid down in a fen/alder carr. Above this horizon are the colluvial sediments associated with climatic deterioration and the onset of the Anglian Glaciation (Marine Isotope Stage - MIS 12).

The sediments of the lake at Q1/B are the temporal equivalent of Unit 4c, the soil horizon that formed at the surface of the intertidal silts of Unit $4 \mathrm{~b}$, and which is found at and outside the lake margins (Table 1). All these sedimentary units and their associated palaeo-land surfaces with abundant faunal and lithic remains have been dated by correlative mammalian and marine invertebrate biostratigraphy to the last temperate stage of the Cromerian Complex MIS 13 524-478ka (Roberts and Parfitt 1999; Candy et al 2015; Roberts and Pope 2018). Analysis of the sediment stack and the fossil faunas, indicates that the archaeology of the Slindon Silts and the lake sediments was deposited during the terminal part of the temperate stage, whereas the artefacts in Units 6 through to 11 were made and discarded during the ensuing Anglian Cold Stage.

Within the sediments encompassed by the excavation of the lake deposits at Q1/B, 459 handaxes and rough-outs were recovered by excavation (Table 2). The lowest material from the channels differs from the later flintwork in that it is, as would be expected, more abraded; the remaining lithics are in mint condition except for the odd pieces reworked from Unit 4b that are slightly polished. The planation surface of the marine sand at Q1/B exhibits signs of soil formation, with evidence for vegetation, animal dung and trampling (Macphail et al in prep), and represents a land surface with a largely in situ lithic signature associated with the butchery of large mammals, especially rhinoceros. Overlying the landsurface are the lake 
deposits that become progressively more calcareous up the sequence. Unit $4 \mathrm{u}$ and its sub units represents the primary freshwater sedimentation, this is a relatively thin unit that has undergone partial erosion and removal during the deposition of the massive silts of Unit 4 . The lithic material found on the surface of Unit 3 most likely represents activity on the southern shore of the lake which was covered as the waterbody expanded. The lithics from Unit $4 \mathrm{u}$ also appear to be from a once intact but eroded landsurface, although the lithics in the main sedimentary body at the margin of the lake, Unit 4, have no discernible landsurfaces associated with them. The flintwork and the fauna were recovered in an exceptional state of preservation but the assemblage is probably best regarded as a palimpsest, as the sediment body has undergone quite extensive soft sediment deformation, as a consequence of pore water expulsion towards the pressure front induced by the loading of the colluvial sediments (Fig $3 b$ ). These processes have almost certainly played a part in the alteration of the unit and its archaeology. The length of time required to deposit the lake sediments and the time equivalent soil formation that resulted in Unit 4c, is hard to access but on the basis of the pedogenesis observed in Unit 4c it is thought to be less than 100 years (Macphail in Roberts and Parfitt 1999), the knapping events are thus interpreted as the result of repeated phases of activity by humans over a few generations of time.

The Boxgrove lithic collection is exceptional in terms of its preservation, due to the nature of its burial and its subsequent taphonomic history, and because of the great quantity of large tools recovered, mainly handaxes. This assemblage is one of the best preserved examples of Acheulean technology in Europe. Typologically, refined ovate handaxes predominate with regular and sharp edges (Roberts and Parfitt 1999). Previous analyses of the debitage indicated that soft hammers were used at the site (Wenban-Smith 1989), and 41 bone and three antler hammers were recovered from the Q1/B and other excavations (Roberts and Parfitt 1999; Stout et al. 2014). The high density of knapping activity, the complete reduction sequences, the technological refinement of the handaxes, and their exceptional preservation, all combine to provide an excellent opportunity to analyze the shaping strategies employed in the production of Acheulean large cutting tools.

\section{Methods}

The basic study of the lithic assemblage was carried out according to the Logical Analytic System (Carbonell et al. 1983, 1992; Rodríguez 2004), which considers technological aspects such as the differential surface exploitation, the percentage of perimeter modified by knapping, the extent of the removals, the direction and the delineation of the retouched edge, and other aspects. We also took into account the four phases in the shaping process defined by Newcomer (1971) and Wenban-Smith (1989): testing, roughing-out, shaping and finishing. The handaxes were assigned to a specific stage of this process according to their technological characteristics which included: the amount of cortex; the distribution of cortex; size and shape of the removals; the possible use of different percussor types; the type of retouch; and the angle between the two faces. This basic technological characterization (García-Medrano 2011) was completed with a systematic metrical analysis of the tools (Figure 4). These measurements, traditionally used in the study of the variability of large tools, were combined into three main indices and used to evaluate each tool's shape: elongation, refinement and edge shape (Bordes 1961; Roe 1968; Crompton and Gowlett 1993; McPherron 1995, 2000).

All the materials, archaeological and experimental have been photographed using a Nikon D3200, and keeping a $90^{\circ}$ angle between the camera and the instrument. The tools have been oriented according to their maximum length. All the photographs have been saved in .NEF and .jpg formats, with an image size of $6016 \times 4000$ pixels. The 3D scans have been made using a Breuckmann's SmartScan, using $250 \mathrm{~mm}$ of Field-of-view lens. The 3D models 
were saved as .ply format. For the analysis of the reduction intensity, we used the SDI (Shipton and Clarkson $2015 \mathrm{a}, \mathrm{b})$ calculated by the: number of scars $(\geq 10 \mathrm{~mm})$ per surface area. In the case of the archaeological materials, the surface area $\left(\mathrm{in}^{2}\right)$ has been calculated using AutoCAD Software. The experimental tools have been scanned so we calculated both the surface area $\left(\mathrm{in}^{2}\right)$ and the volume $\left(\mathrm{in}^{3}\right)$.

The morphological variability of handaxes was analyzed using the geometric morphometric methodology. The extraction of the 2D coordinate data was made using digital photographs taken at frontal and profile views. Coordinate extraction was performed manually with a digitizing programme (tpsDig2, Rohlf 2009), and resampled with 60 equally-spaced points, preserving the original. The pieces were oriented according to their maximum length, beginning form the tip. The starting point was manually digitized. The $X Y$ coordinates of the 60 points per specimen were then saved in a .NTS file, which was later exported to PAST (Paleontological Statistics) programme (Hammer et al. 2001). A 2D Procrustes superimposition of the $\mathrm{XY}$ outline coordinate data was performed, which scaled, rotated and translated the $X Y$ data, bringing all handaxe outlines to a standardized size, orientation and position before subsequent analysis. The multivariate outline data obtained using PAST was projected into two dimensions so that the underlying shape variables could be qualitatively examined and compared. In order to interpret the meaning of the Principal Component Analysis (PCA) results from a morphological perspective, Procrustes superimposed shape data were examined utilizing thin-plate splines to facilitate visualization of shape changes from the group mean along relative warp (i.e., principal component) axes (Hammer and Harper 2006). By examining the morphological deformations and XY plots of specimens from the PCA scatters, it was possible to interpret the shape variation which each principal component encompassed.

The experimental programme was developed by four present-day experienced knappers (García-Medrano, 2017), who were seated parallel to each other, with a set distance of $2 \mathrm{~m}$ between them to avoid contamination of each knapper's reduction debris. Several flint nodules were selected from the calcareous gravel overlying the Q1/B location. Nodules were chosen of variable size and shape, which mirrored those documented in the archaeological record (Roberts and Parfitt 1999). Four morphological types of blank were used: quadrangular and globular (ranging in size between $140-300 \mathrm{~mm}$ in length and $110-230 \mathrm{~mm}$ in width), and tabular and irregular (between $120-280 \mathrm{~mm}$ in length and $90-180 \mathrm{~mm}$ in width). In this case, we use the term blank as any piece of stone from which handaxes will be produced. Twenty nine flint blanks were selected for knapping, resulting in 18 handaxes (Figure 5). Two blanks were discontinued at the rough-out stage, three blanks were taken to the pre-shaping stage, and six blanks broke before completion. A total of 2268 waste flakes $(\geq 20 \mathrm{~mm})$ were produced from the reduction of the blanks. At the beginning of the experiment, all the blanks were measured and weighed. If during the knapping sequence, the blank fragmented or the knapper produced a large flake, then these were also measured and weighed. At the end of the reduction process, the final handaxes were measured, weighed and scanned using a Breuckmann's SmartScan. At this stage of the process, a manual count of the scars was also undertaken. For this set of experiments a size cut-off of $10 \mathrm{~mm}$ was employed for counting scars, avoiding smaller, difficult to identify scars, which were sometimes determined by the quality of the flint, and because in most cases these were derived from the process of regularization of the edge.

\section{The handaxe morphological variability at the Boxgrove-Q1/B}

\subsection{The effects of the knapping sequence}

The operational chain documented at Boxgrove-Q1/B was mainly the result of shaping handaxes. In total $37 \%$ of handaxes were made on nodules $(\mathrm{N}=133)$, while $28 \%$ were made 
on flakes or fragments ( $\mathrm{N}=99)$. In $35 \%$ of cases it is not possible to identify the type of blank

At Boxgrove-Q1/B there is an over-representation of finished tools - handaxes - and also rough-outs. For this paper, a total of 485 pieces were studied, including test nodules $(\mathrm{N}=65)$, rough-outs $(\mathrm{N}=62)$ and finished tools $(\mathrm{N}=358)$. The elongation and refinement indices demonstrate that the metrical heterogeneity is closely related to the shaping stage of the knapping sequence. In the initial stages - testing and roughing-out - the blanks exhibit considerable differences. Nevertheless, the final tools are a very homogeneous group, with very elongated and refined shapes. All of them are oval tools, according to Bordes' and Roe's edge shape indices. But the samples became more homogeneous at the finishing stage of shaping, when the thinning of the piece was undertaken (Table 3). Sometimes, between the initial stages and the final products, it is possible to detect an intermediate phase in the reduction process. This occurred when the blank broke during the roughing-out work, produced by internal fissures in the flint nodules. The breakage produced new morphological blanks of various morphologies, which forced the knapper to re-adapt the process. These events resulted in quadrangular blanks, with the lowest elongation value (Figure 7). However, it should be emphasized that this process occurred at a stage when the rough-outs were very developed, and thus these blanks reveal a clear tendency to more refined shapes.

PCA was applied to look for the morphological changes produced through the whole knapping sequence (Figure 8). PC1 represents the degree of elongation and PC2 refers to the lateral displacement of the tip with respect to the longitudinal axe. The analysis of the Planform (PC1, 28.05\% and PC2, 18.09\%) shows how the shapes vary from a very heterogeneous group morphologically with mainly wider and narrow shapes - in the test and rough-outs - to very elongated shapes - in the final tools. The scatter-plot between PC1 and PC2 to the SDI shows how the SDI increases through the knapping process, presenting the higher values. In addition, we can detect a clear cluster effect on the final handaxe shapes, contrary to the rough-outs, which present a greater degree of dispersion (Figure 9). On the one hand, the breakage of the blanks interrupts the shaping process so, there is a minor relation between morphology and SDI. On the other hand, the analysis of the profiles (PC1, 58.23 and PC2, 15.44\%) shows that the highest morphological variability along the whole sequence is in the thickness of the tools. There is a clear transition from thick and irregular sections to thinner shapes. In both cases, whether based on plan or profile forms, the broken blanks data represent an intermediate group: the pre-shapes of large tools produced after the breakage of rough-out blanks (Table 3, Figure 11).

Throughout our experiment we documented a $40 \%$ breakage rate during the roughing-out work, which was above pre-experimentation expectations. These breaks were mainly produced when working with large blocks/nodules, and generated new quadrangular blanks. As a consequence of the enforced knapping reorganization, the thinning work on the new morphological blank sometimes began using three faces. If the blank was discarded at this point, we found a trifacial blank, with a combination of large scars and residual cortex. As Figure 7 shows, the archaeological and experimental breakage resulted in very similar 
blanks. According to the experimental data, these breaks show a $50-80 \%$ reduction in the mass of the original block (Figure 10).

A second PCA analysis was made on the experimental handaxe data to analyze the morphological changes through the sequence, taking into account: the original blank, the broken blank and the final tool (Figure 11). In the planform analysis, PC1 (45.68\%) refers to the elongation and PC2 (16.20\%) refers to changes in the distal ends (pointed to straight or rounded tips). The initial blanks and the broken blanks comprise very heterogeneous groups, with a high degree of morphological variability. However, moving on from the original shape characteristics, all the final tools exhibit the same properties of narrow shapes with a clear trend to pointed distal ends; accordingly it is the terminal retouch phases that are responsible for the final common planform. In the profile analysis, PC1 $(45.30 \%)$ refers to elongation and PC2 (26.54\%) to differences on the type of distal angle between the two faces. There are clear changes in the three stages: 1) the original blanks are a heterogeneous group with a clear tendency to be less elongated and have wider distal ends; 2) the broken blanks comprise a much more homogeneous group with more elongated profile shapes; 3) the finished tools are all elongated with a clear trend to acute distal angles.

\subsection{The effects of reduction intensity}

Shipton and Clarkson (2015a) define the Scar Density Index (SDI) as an independent measure that characterizes reduction intensity. It works on the principle that the previous scars are never or minimally obscured by the final scars. So, the Index is therefore a record of the mass lost throughout the entire reduction sequence. For the analysis of the SDI (Shipton and Clarkson 2015a,b) the handaxes with a SDI $\leq 4$ were used. The handaxes with an index $>4$ are a small group $(\mathrm{N}=18)$ of "non-orthodox" handaxes - small bifacial tools with a relative high number of removals in relation to their size (Figure 12). This group presents the highest ratio of the SDI to volume $\left(N=17 ; F=23.20 ; p=<0.01 ; R^{2}=0.607\right)$. But this is misleading due to the small size of the blanks prior to shaping. So, as this group introduces noise to the sample and is not representative of the Q1/B shaping, we have decided to exclude them. The SDI shows a strong negative relationship with the final volume of the tools (Table 4), independent of the size and shape characteristics of the original blank.

During the experiment, the complete set of flakes derived from the reduction process was recovered. There are clear differences between the number of recovered flakes and the number of scars on the final tools' surfaces (Figure 13). Only in one case is the number of flakes the same as the number of scars on the handaxe surface. So, contrary to the proposal of Shipton and Clarkson (2015a), there is a significant loss of information through the shaping sequence, and this is dependent on the blank breakage and the intensity of final thinning. Accordingly, was the loss of information sufficient to prevent the quantification of reduction intensity?

Linear regression analysis between volume and SDI on experimental handaxes (Table 5) shows that there is a clear relationship between volume and SDI, which is stronger when based upon the number of scars (ANOVA: $d f=33, F=29.93, P=0.001$ ) than when counting recovered flakes. The scatter plot (Figure 14) reveals a non-linear relationship between SDI and \% of experimental handaxe mass remaining. As SDI increases, the percentage of the mass remaining decreases and this relation is stronger with handaxes made on flakes. The power curve shows a $r^{2}=0,8405$. In this case, the relation between the SDI and the mass remaining is stronger if the knapping begins again after the breakage of the original blank (ANOVA: $\mathrm{df}=19, \mathrm{~F}=6.81, \mathrm{P}=0.01$ ) than if the knapping is continuous on a nodule (ANOVA: $\mathrm{df}=13, \mathrm{~F}=17.45, \mathrm{P}=0.001)$. 
So, the testing and rough-out stages - preparation of the blanks - have a minor effect on the final shape of tools, and this is more closely related to shaping and final thinning works. When the knapping is uninterrupted from the initial reduction through to completion, the shaping chain is very long and the mass is not reflected in the scar pattern of the finished tool. The testing and roughing-out stages only affect the preparation of the blank, and do not have an effect on the final shape. The exception is found in those cases where the original blank shape was so close to the final intended shape that the retouch focused on restricted areas of the piece, with other parts left unmodified (i.e. Fig. 4, handaxe n.30105).

\subsection{The effects of the distal tranchet}

The Boxgrove handaxes are characterized not only by the extensive shaping sequences and intensive thinning but also by a specific distal retouch known as tranchet flake removals (Bergman and Roberts 1988; Roberts and Parfitt 1999; Field 2005; Pope and Roberts 2005). Shipton and Clarkson (2015b) consider this type of retouch as partly responsible for the morphological variation between the final shapes at Boxgrove. Here, the distal end of handaxes from the archaeological sample was categorized, based upon the presence or absence of tranchet removals and the intensity and distribution of this distal retouch (Figure 15). So, we have considered: Type 0) No tranchet removals; Type I) Distal tranchet: a transverse blow which gives a straight or convex distal tip; Type II) Lateral-distal tranchet: a longitudinal blow producing a long lateral edge and shorter distal tip edge. In some cases, this generates a shift in the distal point; Type III) Invasive tranchet, often derived from several successive phases of oblique tranchet retouch. Type IV). Unsuccessful tranchet, derived from the breakage of the distal tip, generating irregular distal edges.

These distal end morphologies of handaxes were also analyzed by PCA (Figure 16). PC1 represents the lateral displacement of the maximum axis. PC2 represents narrow and more elongated shapes vs. wider shapes. The PCA of the planform (PC1, 22,06\%; PC2, 20,49\%) and profile form (PC1, 36,04\%; PC2, 24,67\%) show that the invasive tranchet (Type III) and the unsuccessful tranchet (Type IV) generate significant modification of the distal shape of tools, producing more quadrangular and less elongated morphologies with straight or wider convex distal edges. Tranchet types I and II do not produce statistically observable changes. The profile forms also show morphological changes but with minor statistical impact. In this case, the invasive retouch corresponds with thinner distal shapes, and generates more accurate distal angles. Finally, unsuccessful tranchet removals generate blunt distal angles. So, the distal removals only have an effect on the morphology of tools when there is a series of blows or if the retouch fails and it generates a breaking of the distal tips. Thus, systematic re-sharpening as the cause of shape variation seems highly unlikely, which could be related to the short use-life of the Boxgrove handaxes.

\section{Discussion and conclusions}

The paradoxical character of the Acheulean, which shows both stability and variability, has been discussed on many occasions and the versatility, durability and fashionable character of its principal tool type - the handaxe - has been the focus of most attention within the scientific community. Boxgrove-Q1/B and its lithic assemblage is one of the best sites in the European Middle Pleistocene from which to understand the shaping strategies, the morphological changes and the variability between handaxes. The methods used in this paper have demonstrated their suitability for understanding these processes and outcomes. The advantages in the use of the geometric morphometric technique, combined with PCA, is well known and has mainly been used to compare the morphology of handaxes of different raw materials (Eren et al. 2014; Lycett et al. 2016), handaxes of different periods (lovita and McPherron 2011) or different parts of the same operational chain (Shipton and Clarkson 2015b). In this paper, these techniques have been applied and complemented traditional 
technological descriptions and metrical analysis. They have not only helped to analyze the final morphology of tools but also helped to define accurately the shaping process and how the reduction proceeded from original blank to final form.

SDI has been shown to be an appropriate index that characterizes reduction intensity. But contrary to the position held by Shipton and Clarkson (2015a), in the case of Boxgrove, the small and invasive scars generated during the shaping, especially during the finishing stages of the knapping, obscured the first stages of reduction, due to the intensity of final retouching. There was a significant loss of material during the first steps of the knapping sequence, but both the experimental and the archaeological data show that this phase of reduction had a minor effect on the final morphology of tools, which was imposed during the shaping and thinning stages. In the case of Boxgrove, the last phase was especially intense and the data presented here agree with Shipton and Clarkson (2015b) who suggest that the Boxgrove handaxes kept their morphology despite the intensity of the retouch. Table 5 shows that for the total shaping stages there are no significant relationships between the reduction intensity and shape. Furthermore, the PCA analysis of the final morphology of tools showed that tranchet removals had little effect on distal variation from re-sharpening.

The analyses and experimental programme have also given insights into the raw material at Boxgrove. From the perspective of a present day knapper, there was an abundance of goodquality flint nodules of varying shape and size, which enabled a wide range of technical possibilities. But some morphological variables would have only been apparent during certain parts of the operational chain, where procedures had to adapt. The knapping of small-sized nodules involved the simplest and shortest shaping process, using marginal retouch on the lateral edges. Conversely, the knapping of large nodules resulted in the longest and most complex sequences. In these cases, intense roughing-out was followed by a long shaping stage where the knappers gave the overall form to the blank through large removals, and then finished with intense lateral thinning and work on the distal end of the handaxes.

Regardless of the high quality of Boxgrove flint, both the archaeological assemblage and the experimental programme showed frequent internal fissures, which often resulted in fracturing during the roughing-out stage. Breakage is considered as an intermediate phase in the shaping sequence because it often led to the loss of around $80 \%$ of the mass that enforced reorganization of the knapping and restarting of the reduction. Despite these breakage patterns, the resulting handaxes have the same morphological aspect and technical characteristics as the other handaxes with uninterrupted reduction sequences.

Importantly, despite the variables of blank size and shape, together with the problems of frequent breakage, the Boxgrove hominins were still able to arrive at a common goal: elongated ovate handaxes with convex distal ends and wider proximal butts. The hominins clearly had a deep knowledge of their raw material and near-perfect control over the shaping technique. They were therefore able to solve technical problems and physical differences between nodules to create forms that were standardized in shape. So, the end goal of the operational chain was set in the knapper's mind, as were the pathways to production. Despite the effects of raw material constraints and the effect of reduction intensity on the final shape of handaxes, it was the knapper's mental template that was the consistent and persistent determinant in the final handaxe morphology. The concept of a 'mental template' has been heavily scrutinized over the last 25 years (Ashton and McNabb 1994; White 1998b; Ashton and White 2003). But through better understanding of the effects of raw materials and, in Britain, better resolution of the chronology there are now patterns beginning to emerge of specific handaxe types appearing in space and time.

Boxgrove is one of the few Lower Palaeolithic sites where the life history of handaxes and hence the intentions of the hominins can be studied from raw material selection, manufacture 
and use to eventual discard. Despite the complexity of these processes this study has shown specific problems, with the overarching aim of producing elongated ovate handaxes. The results of the current work also have a bearing on how the Boxgrove landscape was used. The scarcity of re-sharpening is contrary to some interpretations (McPherron 1999; Emery 2010), but supports other views of the short use-life of the Boxgrove handaxes as reflected in the number of large tools at Q1/B (Pitts and Roberts 1997; Gamble 1999). Without doubt, access to abundant good-quality flint nodules led to frequent discard of used handaxes and production of new tools. The accumulation of handaxes at sites like Q1/B was probably due to a combination of the extended use of a fixed resource - the lake/waterhole - and the extensive butchery of large mammals, notably rhinoceros. As far as can be discerned, handaxes were only mobile in the immediate Boxgrove landscape in the sense that they were sometimes taken in finished or near finished form to other kill sites such as Q1/A (Pope and Roberts 2005), whilst at other locales such as Q2/GTP17 and Q2/A, they were made at the kill site from nodules or rough-outs.

The handaxe assemblage from Corfe Mullen in Dorset, lies $90 \mathrm{~km}$ to the west of Boxgrove and provides some parallels with that site. The assemblage was largely collected in the late $19^{\text {th }}$ and early $20^{\text {th }}$ centuries and seems to be composed of at least two different elements (McNabb et al. 2012; Davis 2013). One group of handaxes consists of ovates often with tranchet sharpening that is strongly reminiscent of Boxgrove. The site is not securely dated, but its position on one of the higher terraces of the Solent River system suggests an MIS 13 age (Westaway et al. 2006; Ashton \& Hosfield 2010; McNabb et al. 2012; Davis 2013). Ovates are also a characteristic of other British MIS 13 sites, such as High Lodge and Warren Hill, both in Suffolk (Ashton et al. 1992; Bridgland et al. 1995; Moncel et al. 2015; Bridgland and White 2015; White 2015).

Possible patterning in the later stages of the British Lower Palaeolithic has also been identified. Due to an exceptional environmental record several sites can be assigned to the different substages of MIS 11 (Ashton et al. 2008, 2016; White et al. 2013). In the Thames Valley, the assemblages from the Middle Gravels at Swanscombe (Kent) have been assigned to MIS $11 \mathrm{c}$ and the handaxes adhere to small, pointed forms. By contrast, very finely-made twisted ovates dominate the assemblages from the Upper Loam at Swanscombe, but also from the nearby sites at Greenhithe and Dartford. All these sites have been attributed to MIS 11a (White 1998a; White et al. 2013). The MIS 11 handaxe record for East Anglia is not quite so clear in part due to small assemblages, but there are hints of a regional pattern that is different to the Thames (Ashton 2016). For MIS 9 patterning has also been discerned where it has been noted that many of the assemblages include an array of more unusual forms, such as ficrons and cleavers (Wenban-Smith 2004; Bridgland and White 2015; White 2015).

As with Boxgrove, there seem to be clear pathways of production with apparent goals in mind. Ashton et al. (2016; Ashton 2017) have attempted to explain the patterns, but on a European scale. They suggest that during stable environments hominins became habituated within local landscapes, which influenced the way they behaved and the material culture that they produced. 'Landscapes of habit' produced patterns of behavior that were affected by the distribution and type of resources, whether it be the configuration of the land and its drainage network, natural shelters, plant and animal foods or indeed lithic raw materials. Stable habitats produced localized material cultures, which reinforced the bonds within any given situation. The papers also argue that underpinning these local expressions of group behaviour was the broader 'Acheulean package', which included a wider suite of technological practices, such as fire use (Mania 1995; Gowlett et al. 2005; Molines et al. 2005; Preece et al. 2006; Roebroeks and Villa 2011), hunting with spears (Warren 1911; Thieme 1997; Schoch et al. 2015) and the use of hides (Voormolen 2008). If stable 
environments produced localized patterns of behavior, then changes in climate brought in instability and movement of populations. For Britain, the extreme oscillations in climate and environment between MIS 13 and MIS 9 brought population movement and the regular introduction of new expressions of the underlying suite of technologies, which included a variety in handaxe form. For Boxgrove, where there were few limits on the abundance of flint raw material, hominins consistently chose to make elongated ovates with convex distal ends and wider proximal butts, frequently sharpened by tranchet removals.

The influence of local substrates and the accumulative technological processes resulting from successive population movements can explain the variability and diversity of the technological strategies within bifacial technology (Moncel et al. in press). However, the strength of the handaxe mental template seems to go further. It clearly combines a morphological, a processual as well as functional common dimension, and continues to be what structurally allows us to define the Acheulean technocomplex.

\section{References}

Antón, S. C. (2003). Natural history of Homo erectus. Yearbook of Physical Anthropology, 46, 126-170.

Ashton, N. (2008). Transport, curation and resharpening of lithics in the Lower Middle Paleolithic. Lithics, 29, 6-17.

Ashton, N. M. (2016). The human occupation of Britain during the Hoxnian Interglacial. Quaternary International, 409, 41-53.

Ashton, N. M. (2017). Landscapes of habit and persistent places during MIS 11 in Europe. A return journey from Britain. In M. Pope, J. McNabb \& C. S. Gamble (Eds.), Crossing the Threshold. Dynamic Transformation and Persistent Places During the Middle Pleistocene. (pp. 142-164) Routledge, London.

Ashton, N., Hosfield, R. (2010). Mapping the human record in the British early Palaeolithic: evidence from the Solent River system. Journal of Quaternary Science, 25, 737-753.

Ashton, N., McNabb, J. (1994). Bifaces in perspective. In N. Ashton \& A. David (Eds.), Stories in stone. Lithic Studies Society Occasional Paper, 4, 182-191.

Ashton, N., White, M. J. (2003). Bifaces and Raw Materials: flexible flaking in the British Early Paleolithic. In M. Soressi \& H. L. Dibble (Eds.), Multiple Approaches to the Study of Bifacial Technologies (pp. 109-123). Pennsylvania: Museum of Archaeology and Anthropology.

Ashton, N. M, Cook, J., Lewis, S. G., Rose, J. (Eds). (1992). High Lodge: Excavations by G. de G. Sieveking 1962-68 and J. Cook 1988. London: British Museum Press.

Ashton, N., Lewis, S. G., Parfitt, S. A., Penkman, K. E. H., Russell Coope, G. (2008). New evidence for complex climate change in MIS 11 from Hoxne, Suffolk, UK. Quaternary Science Review, 27(7-8), 652-668.

Ashton, N. M., Lewis, S. G., Parfitt, S. A., Davis R. J, Stringer, C. B. (2016). Handaxe and non-handaxe assemblages during Marine Isotope Stage 11 in northern Europe: Recent investigations at Barnham, Suffolk, UK. Journal of Quaternary Science, 31, 837-843.

Barnes, R. S. K. (1980). Coastal Lagoons. Cambridge: Cambridge University Press.

Bergman, C. A., Roberts, M. B. (1988). Flaking technology at the Acheulean site of Boxgrove (West Sussex, England). Revue Archéologique de Picardie, 1(1), 105-113.

Bordes, F. (1961). Typologie du Paléolithique Acient et Moyen. Paris: Centre National de la Recherche Scientifique.

Bridgland, D. R. and White, M. J. (2015). Chronological variations in handaxes: patterns detected from fluvial archives in NW Europe. Journal of Archaeological Science, 30, 623638.

Bridgland, D. R., Lewis, S. G., Wymer, J. J. (1995). Middle Pleistocene stratigraphy and archaeology around Mildenhall and Icklingham, Suffolk: report on the Geologists' 
Association Field Meeting, 27th June 1992. Proccedings of the Geologists' Association, 106, 57-69.

Candy, I., Schreve, D., and White, T.S. (2015). MIS13-12 in Britain and the North Atlantic: understanding the palaeoclimatic context of the earliest Acheulean. Journal of Quaternary Science, 30(7), 593-609.Carbonell, E., Guibaud, M., Mora, R. (1983). Utilización de la lógica analítica para el estudio de los tecnocomplejos de cantos tallados. Cahier Noir, 1, 3-79.

Carbonell, E., Rodríguez Alvarez, X. P., Sala i Ramos, R., Vaquero, M. (1992). New elements of the logical analitic system. Cahier Noir, 6 .

Clark, J. D. (1994). The Acheulian industrial complex in Africa and elsewhere. In R. S. Corrucin \& R. L. Ciochon (Eds.), Integrative paths to the past Paleoanthropology advances in honor of F. Clark Howell (pp. 451-469). New Yersey: Pretice-Hall.

Clarkson, C. (2013). Measuring core reduction using 3D flake scar density: a test case of changing core reduction at Klasies River Mouth, South Africa. Journal of Archaeological Science, 40(12), 4348-4357.

Crompton, R. H., Gowlett, J. A. J. (1993). Allometry and multidimensional form in Acheulean bifaces from Kilombe, Kenya. Journal of Human Evolution, 25, 175-199.

Davis, R. J. (2013). Palaeolithic Archaeology of the Solent River: Human Settlement History and Technology. Ph.D. Dissertation, University of Reading. UK.

Emery, K. (2010). Reexamination of variability in handaxe form in the British Paleolithic. Ph.D. Dissertation, UCL, UK.

Eren, M. I., Roos, C. I., Story, B. A., von Cramon-Taubadel, N., Lycett, S. J. (2014). The role of raw material differences in stone tool shape variation: an experimental assessment. Journal of Archaeological Science, 49, 472-487.

Field, A. S. (2005). Transformations in dividuality: personhood and palaeoliths in the Middle Pleistocene. In C. Gamble \& M. Porr (Eds.), The hominid individual in context: Archaeological investigations of Lower \& Middle Palaeolithic landscapes, locales \& artefacts (pp. 29-49). London: Routledge.

Gamble, C. (1999). The Palaeolithic societies of Europe. Cambridge: World Archeology.

García-Medrano, P. (2011). Los sistemas técnicos del Pleistoceno Medio en el Oeste de Europa. Cadenas operativas y procesos de configuración en los conjuntos líticos de Galería y Gran Dolina-TD10-1 (Sierra de Atapuerca, Burgos, España) y Boxgrove (Sussex, Inglaterra). Ph.D. Dissertation, Universidad de Burgos, Spain.

García-Medrano, P. (2017). Replicating the handaxe shaping strategies from Boxgrove (Sussex, UK), in: Alonso, R., Baena, J., Canales, D. (Eds.), Playing with the time. Experimental archaeology and the study of the past, Servicio de Publicaciones de la UAM, Madrid, pp. 19-24.

Goren-Inbar, N. (2011). Culture and cognition in the Acheulian industry: a case study from Gesher Benot Ya'aqov. Philosophical Transactions of the Royal Society B, 366(1567), 1038-1049.

Gowlett, J. A. J. (1986). Culture and conceptualisation: the Oldowan-Acheulian gradient. In G. N. Bailey \& P. Callow (Eds.), Stone Age in Prehistory Studies in memory of Charles Mc Burney (pp. 243-260). Cambridge: Cambridge University.

Gowlett, J. A. J. (2006). The elements of design form in Acheulian bifaces: modes, modalities, rules and language. In N. Goren-Inbar and G. Sharon (Eds.), Axe Age: Acheulian tool-making from Quarry to discard (pp. 1-20). London: Equinox.

Gowlett, J. A. J. (2011). Innovation and the Evolution of Human Behavior. The Vital Sense of Proportion: Transformation, Golden Section, and 1:2 Preference in Acheulean Bifaces. PaleoAnthropol, Special Issue, 174-187.

Gowlett, J. A. J., Crompton, R. H. (1994). Kariandusi: Acheulian morphology and the question of allometry. African Archaeological Review, 12, 1-40.

Gowlett, J. A. J., Hallos, J., Hounsell, S., Brant, V., Debenham, N. C. (2005). Beeches Pit archaeology, assemblage dynamics and early fire history of a Middle Pleistocene site in East Anglia, UK. Eurasian Prehistory, 3, 3-38. 
Hammer, Ø., Harper, D. A. T. (2006). Paleontological Data Analysis. Malden: Blackwell Publishing.

Hammer, Ø., Harper, D. A. T., Ryan, P. D. (2001). PAST: Paleontological statistics package for education and data analysis. Paleontologia Electronica, 4(1), 9.

Holmes, J. A., Atkinson, T., Fiona Darbyshire, D. P., Horne, D. J., Joordans, J., Roberts, M. B., Sinka, K. J., Whittaker, J. E. (2010). Middle Pleistocene climate and hydrological environments at the Boxgrove hominin site (West Sussex, UK) from ostracod records. Quaternary Science Review, 29(13-14), 1515-1527.

lovita, R., McPherron, S. (2011). The handaxe reloaded: A morphometric reassessment of Acheulian and Middle Paleolithic handaxes. Journal of Human Evolution, 61, 61-74.

Isaac, G. (1969). Studies of early culture in East Africa. World Archaeology, 1(1), 1-28.

Isaac, G. (1986). Fundation stones: early artefacts as indicators of activities and abilities. In G.N. Bailey \& P. Callow (Eds.), Stone age prehistory (pp. 221-241). Cambridge: Cambridge University Press.

Kohn, M., Mithen, S. (1999.) Handaxes: products of sexual selection? Antiquity, 73, 518-526.

Lycett, S. J., Schillinger, K., Eren, M. I., von Cramon-Taubadel, N., Mesoudi, A. (2016). Factors affecting Acheulean handaxe variation: Experimental insights, microevolutionary processes, and macroevolutionary outcomes. Quaternary International, 411 Part B, 386401.

Mania, D. (1995). The earliest occupation of Europe: the Elbe-Saaleregion (Germany). In W. Roebroeks \& T. van Kolfschoten (Eds.), The Earliest Occupation of Europe (pp. 85-102). Leiden: University of Leiden and European Science Foundation.

Macphail, R.I. (1999). Sediment micromorphology. In M.B. Roberts \& S.A. Parfitt (Eds.), Boxgrove: A Middle Pleistocene hominid site at Eartham Quarry, Boxgrove, West Sussex (pp. 118-149). London: English Heritage Monograph Series. Archaeological Report 17.

Macphail, R.I., Acott, T.G. and Crowther, J. (In prep) In M.B. Roberts, S.A. Parfitt \& M.I. Pope (Eds.), Boxgrove: an early Middle Pleistocene site at the Q1/B waterhole, West Sussex, UK. Excavation and research 1993-2012. Spoilheap Monograph. Suffolk: Lavenham Press.

McNabb, J., Hosfield, R. T., Dearling, K., Barker, D., Strutt, K., Cole, J., Bates, M. R., Toms, P. (2012). Recent work at the Lower Palaeolithic site of Corfe Mullen, Dorset, England. Proceedings of the Prehistoric Society, 78, 35-50.

McPherron, S. P. (1995). A reexamination of the british biface data. Lithics, 16, 47-63.

McPherron, S. P. (1999). Ovate and pointed handaxe assemblages: two points make a line. Préhistoire Européenne, 14, 9-32.

McPherron, S.P. (2000). Handaxes as a measure of the mental capabilities of early hominids. Journal of Archaeological Science, 27, 655-663.

Mithen, S. (2005). The Singing Neanderthals: The Origins of Music, Language, Mind and Body. London: Weidenfeld and Nicolson.

Molines, N., Monnier, J. L., Hinguant, S., Hallegouet, B. (2005). L'Acheuléen del'ouest de la France: apports du site de Menez Dregan I (Plouhinec, Finistère, France). In M. Molines, M. H. Moncel, J. L. Monnier (Eds.), Les Premiers Peuplements en Europe (pp. 533-544). Oxford: BAR International Series.

Moncel, M. H., Ashton, N., Lamotte, A., Tuffreau, A., Cliquet, D., Despriée, J. (2015). Northwest Europe early Acheulian. Journal of Anthropological Archaeology, 40, 302-331.

Moncel, M. H., Arzarello, M., Boëda, É., Bonilauri, S., Chevrierc, B., Gaillarda, C., Forestiera, H., Yinghuad, L., Sémaha, F., Zeitoune, V. (In press). Assemblages with bifacial tools in Eurasia (third part). Considerations on the bifacial phenomenon throughout Eurasia Assemblages. C.R. Palevol, doi: 10.1016/j.crpv.2015.11.007.

Newcomer, M. H. (1971). Some quantitative experiments in handaxe manufacture. World Archaeology, 3(1), 85-104.

Nowell, A., Lee Chang, M. (2009). The case against sexual selection as an explanation of Handaxe Morphology. PaleoAnthropology, 77-88. 
Petraglia, M. D. (2006). The Indian Acheulian in global perspective. In N. Goren-Inbar \& G. Sharon (Eds.), Axe Age: Acheulian Tool-making from Quarry to Discard (pp. 389-414). London: Equinox.

Pitts, M., Roberts, M. B. (1997). Fairweather Eden: life half a million years ago as revealed by the excavations at Boxgrove. New York: Fromm International ed.

Pope, M., Roberts, M. B. (2005). Observations on the relationship between individuals and artefact scatters at the Middle Pleistocene site of Boxgrove, West Sussex. In C. Gamble \& M. Porr (Eds.), The hominid individual in context: Archaeological investigations of Lower \& Middle Palaeolithic landscapes, locales \& artefacts (pp. 81-97). London: Routledge.

Preece, R. C., Gowlett, J. A. J., Parfitt, S. A., Bridgland, D. R., Lewis, S. G. (2006). Humans in the Hoxnian: habitat, context and fire use at Beeches Pit, West Stow, Suffolk, UK. Journal of Quaternary Science, 21, 485-96.

Roberts, M., Parfitt, S. (1999). Boxgrove. A Middle Pleistocene hominid site at Eartham Quarry, Boxgrove, West Sussex. London: English Heritage.

Roberts, M. B., Pope, M. I. (2009). The archaeological and sedimentary records from Boxgrove and Slindon. In R. M. Briant, M. R. Bates, R. T. Hosfield, F. F. Wenban-Smith (Eds.), The Quaternary of the Solent Basin and West Sussex Raised Beaches (pp. 96122). London: Quaternary Research Association Field Guide.

Roberts, M., Pope, M. (2018). The Boxgrove wider area project. Mapping the early Middle Pleistocene deposits of the Slindon Formation across the Coastal Plain of West Sussex and eastern Hampshire. Spoilheap Monograph 15. Suffolk: Lavenham Press.. Roche, $\mathrm{H}$. (2005). From simple flaking to shaping: Stone knapping evolution among early hominins. In V. Roux \& B. Bril (Eds.), Stone Knapping: The Necessary Conditions for a Uniquely Hominin Behaviour (pp. 35-48). Cambridge: McDonald Institute for Archaeological Research.

Rodríguez, X. P. (2004). Technical systems of lithic production in the Lower and Middle Pleistocene of the Iberian Peninsula. Technological variability between north-eastern sites and the Sierra de Atapuerca sites. Oxford: BAR International Series, 1323.

Roe, D. (1968). British Lower and Middle Palaeolithic handaxe groups. Proceedings of the Prehistoric Society, 34, 1-82.

Roebroeks W., Villa P. (2011). On the earliest evidence for habitual use of fire in Europe. Proceedings of the National Academy of Sciences, 108, 5209-5214.

Rohlf, F. J. ( 2009). tpsDig2. http://life.bio.sunysb.edu/morph/morphmet/tpsdig2w32.exe.

Schoch, W. H., Bigga G., Böhner, U., Richterd, P., Terberger, T. (2015). New insights on the wooden weapons from the Paleolithic site of Schöningen. Journal of Human Evolution, 89, 214-225.

Sharon, G. (2007). Acheulian Large Flake Industries: technology, chronology, and significance. Oxford: BAR International Series, 1701.

Sharon, G., 2008. The impact of raw material on Acheulian large flake production. Journal of Archaeological Science, 35, 1329-1344.

Shipton, C., Clarkson, C., Pal, J.N., Jones, S. C., Roberts, R. G., Harris, C., Gupta, M.C., Ditchfield, P. W., Petraglia, M. D. (2013). Generativity, hierarchical action and recursion in the technology of the Acheulean to Middle Palaeolithic transition: A perspective from Patpara, the Son Valley, India. Journal of Human Evolution, 65(2), 93-108.

Shipton, C., Clarkson, C. (2015a). Flake scar density and handaxe reduction intensity. Journal of Archaeological Science: Reports, 2, 169-175.

Shipton, C., Clarkson, C. (2015b). Handaxe reduction and its influence on shape: an experimental test and archaeological case study. Journal of Archaeological Science: Reports, 3, 408-419.

Spikins, P. (2012). Goodwill hunting? Debates over the 'meaning' of Lower Palaeolithic handaxe form revisited. World Archaeology, 44, 378-392.

Stout, D. (2002). Skill and cognition in stone tool production. An ethnographic case study from Iran Jaya. Current Anthropology, 43, 693-722. 
Stout, D. (2011). Stone toolmaking and the evolution of human culture and cognition. Philosophical Transactions of the Royal Society B, 366, 1050-1059.

Stout, D. (2015). Cognitive demands of Lower Paleolithic toolmaking. PLoS ONE. 10(e0121804), doi: 10.1371/journal.pone.0121804.

Stout, D., Apel, J., Commander, J., Roberts, M. (2014). Late Acheulean technology and cognition at Boxgrove, UK. Journal of Archaeological Science, 41, 576-590.

Thieme H. (1997). Lower Palaeolithic hunting spears from Germany. Nature. 385, 807-810.

Toth N. (1991). The importance of experimental replicative and functional studies in Paleolithic Archaeology. In J. D. Clark (Ed.), Cultural beginnings: approaches to understanding early hominid life-ways in the African savanna (pp. 109-124). Bonn: Rudolf Habelt.

Voormolen B. (2008). Ancient Hunters, Modern Butchers. Schöningen 13II-4, a Kill-butchery Site Dating from the Northwest European Lower Palaeolithic. Ph.D. Dissertation, University of Leiden, Netherlands.

Warren, S. H. (1911). Palaeolithic wooden spear. Quarterly Journal of the Geological Society of London, 67, 119.

Wenban-Smith, F. F. (1989). The use of canonical variates for determination of biface manufacturing technology at Boxgrove Lower Paleolithic site and the behavioural implications of this technology. Journal of Archaeological Science, 16, 17-26.

Wenban-Smith, F. F. (2004). Handaxe typology and Lower Paleolithic cultural development: ficrons, cleavers and two giant handaxes from Cuxton. Lithics, 25, 11-21.

Wenban-Smith, F. F., Ashton, N. (1998). Raw material and lithic technology. In N. Ashton, S. G. Lewis \& S. Parfitt (Eds), Excavations at the Lower Palaeolithic Site at East Farm, Barnham, Suffolk 1989-94 (pp. 237-244). London: British Museum Occasional Paper.

Wenban-Smith, F. F., Gamble, C., Apsimon, A. (2000). The Lower Palaeolithic site at Red Barns, Portchester, Hampshire: Bifacial Technology, raw material quality and organisation of archaic behaviour. Proceedings of the Prehistoric Society, 66, 209-255.

Westaway, R., Bridgland, D., White, M. (2006). The Quaternary uplift history of central southern England from the terraces of the Solent river system and nearby raised beaches. Quaternary Science Review, 25, 2212-2250.

White, M. J. (1995). Raw materials and biface variability in Southern Britain: a preliminary examination. Lithics, 15, 1-20.

White, M. J. (1998a). Twisted ovate bifaces in the British Lower Palaeolithic: some observations and implications. In N. Ashton, F. Healy, P. Pettitt (Eds.), Stone Age Archaeology: Essays in Honour of John Wymer (pp. 98-104). Oxford: Oxbow Books.

White, M. J. (1998b). On the significance of Acheulean biface variability in southern Britain. Proceedings of the Prehistoric Society, 64, 15-44.

White, M. J. (2006). Axeing claevers: reflections on broad-tipped large cutting tools in the British earlier Paleolithic. In N. Goren-Inbar and G. Sharon (Eds.), Axe Age Acheulian tool-making from quarry to discard (pp. 365-386). London: Equinox.

White, M. J. (2015). Dancing to the rhythms of the biotidal zone: settlement history and culture history in Middle Pleistocene Britain. In F. Wenban-Smith, F. Coward \& R. Hosfield (Eds.), Settlement, Society and Cognition in Human Evolution: Landscapes in Mind (pp. 154-173). Cambridge: Cambridge University Press.

White, T. S., Preece, R. C., Whittaker, J. E. (2013). Molluscan and ostracod successions from Dierden's Pit, Swanscombe: insights into the fluvial history, sea-level record and human occupation of the Hoxnian Thames. Quaternary Science Review, 70, 73-90.

Wynn T. (1989). The evolution of spatial competence. University of Illinois Press.

Wynn, T. (1995). Handaxe enigmas. World Archaeology, 27(1), 10-24.

Wynn, T. (2002). Archaeology and cognitive evolution. Behavioural and Brain Sciences, 25(3), 389-402.

\section{List of Figures}


Figure 1. Location map of the Boxgrove site, showing the mapped distribution of the Slindon Formation

Figure 2. Open excavation area at Boxgrove-Q1/B, the figures in the foreground are excavating through the deposits of Unit 5ac shown in Figures 3a,b. The area behind them has been taken down through the surface of the marine sand. The colluvial and solifluction deposits of the Eartham Formation can be seen overlying the temperate sediments of the lake (Table 1).

Figure 3. A) The marine/freshwater/terrestrial sequence at Q1/B Trench 23 showing the channel and its associated infill (Unit 3c), cutting through the marine Slindon Sand (Unit 3 ). The channels deposits are overlain by the freshwater sediments of Units $4 u, 4$ and 5ac. Note the presence of the mineralised organic horizon Unit 5a which completely covers the freshwater deposits at this part of the site (see Table 1). B) Handaxe in situ in the freshwater silts of Unit 4 at $\mathrm{Q} 1 / \mathrm{B}$, the waterhole/lake site, note the deformation structures throughout the sequence (Scales in $0.50 \mathrm{~m}$ divisions).

Figure 4. Set of measurements and indices considered, expressed as name and initials.

Figure 5. Total set of 18 experimental handaxes made on flint from Boxgrove.

Figure 6. a) Summary of the shaping strategies documented at $Q / 1 B$, Boxgrove (modified from García-Medrano, 2011). Note that multiple options exist to get the final shapes. Blue square inset shows the possible use of irregular fragments (resulting from the initial roughing-out phase) as cores. b) Boxgrove-Q1/B handaxe examples, showing morphological variability (from top to bottom: 30157, 30105, 10575, 5781, 5162).

Figure 7. Blank breaks produced during the shaping process. a) Two experimental examples. b) Two archaeological examples from Boxgrove-Q1/B (505, 30743).

Figure 8. Principal Components 1 and 2 morphometric shape data of the Planform and Profile form, showing morphological variations (Boxgrove-Q1/B), according to the different shaping stages: testing (black dots), rough-outs (green diamonds), fragmented roughouts (turquoise triangles), shaping (blue squares) and finishing (red crosses). On the left, the PCA scatter plots with 95\% ellipses. On the right, 95\% confidence interval distribution and the shape variations. (See online paper for colour version)

Figure 9. Scatter-plot of the archaeological remains of PC1 and PC2 against the SDI, according to the shaping stages: rough-outs (green diamonds), fragmented rough-outs (turquoise triangles), shaping (blue squares) and finishing (red crosses). No tested nodules have been included.

Figure 10. Boxplot of the mass lost (in gr.) through the experimental sequence, considering original nodule mass; mass of the fragmented blank, final tool mass and mass of final tool made on fragmented blank).

Figure 11. Principal Components 1 and 2 morphometric shape data of the experimental handaxe planform and profile, showing morphological variations according to original blanks (green diamonds), blanks broken in reduction (black dots) and the finished handaxes (blue squares). On the left are the PCA scatter plots and on the right, 95\% confidence interval distribution and the shape variations. (See online paper for colour version.)

Figure 12. Some archaeological examples of non-orthodox handaxes from Boxgrove-Q1/B (from top to bottom: 9078, 1997, 4533).

Figure 13. Boxplot of the number $(N)$ of recovered flakes and counted scars derived from the experimental session.

Figure 14. Scatter plot of remaining percentage of the original mass against SDI for experimental handaxes.

Figure 15. Five types of distal ends considered, according to the characteristics of the tranchet removal.

Figure 16. Principal Components 1 and 2 morphometric shape data of the handaxes planform and profile (Boxgrove-Q1/B), showing morphological variations according to the different types of tranchet considered: No tranchet (turquoise triangles), distal tranchet (blue squares), lateral-distal tranchet (green diamonds), invasive tranchet (red crosses) 
and unsuccessful tranchet (pink squares). On the left, the PCA scatter plots with 95\% ellipses. On the right, 95\% confidence interval distribution and the shape variations. (See online paper for colour version.)

\section{List of Tables}

Table 1. Stratigraphic relationship between the standard Boxgrove sequence and that recorded at Quarry 1/B, the spring fed waterhole. Unit 4c and its chronostratigraphic correlatives are shaded in green [outlined in black], deposition of these units is thought to be on a timescale of $<100-150$ years. The handaxes referred to in this paper are from Units $3 / 4$ through to Unit 5 ac (Figs $3 a, 3 b$ ). Unit 7, yellow, is a sedimentary unit that is in continuous formation until the burial of the cliff by mass movement deposits, this unit was not revealed at Q1/B. (Not to scale).

Table 2. Total number of handaxes excavated from the lake deposits (3c-4), marginal soil horizon (4c), fen carr (5a), colluvial deposits (6b-8b).

Table 3. Shape indices derived from linear variables.

Table 4. Linear regression analysis on experimental handaxes between SDI and the volume of the final tools. From one side, we have considered the SDI based on both counted scars and recovered flakes. On the other side, we have distinguished if the original blanks were nodules or fragments.

Table 5. Linear regression analyses on Q/1B assemblage, for SDI against PC1 and PC2 by shaping stage. 


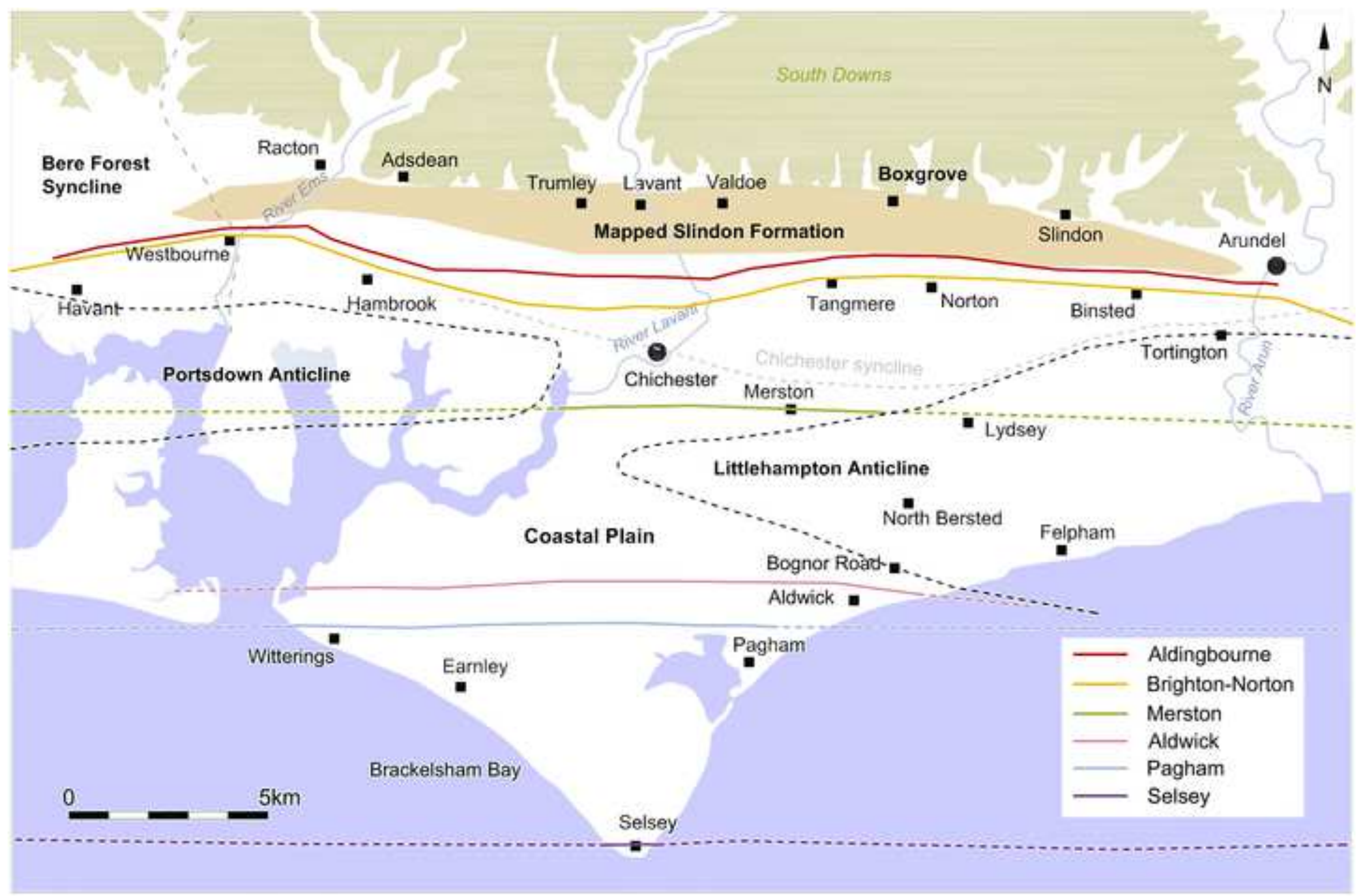

Bere Forest

Syncline

\section{Mapped Slindon Formation}

Boxgrove

促 

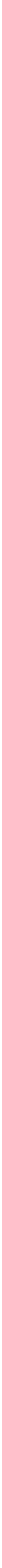

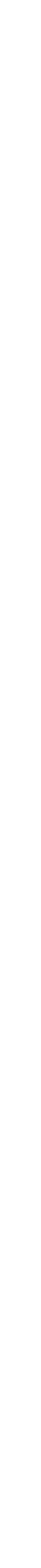

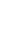




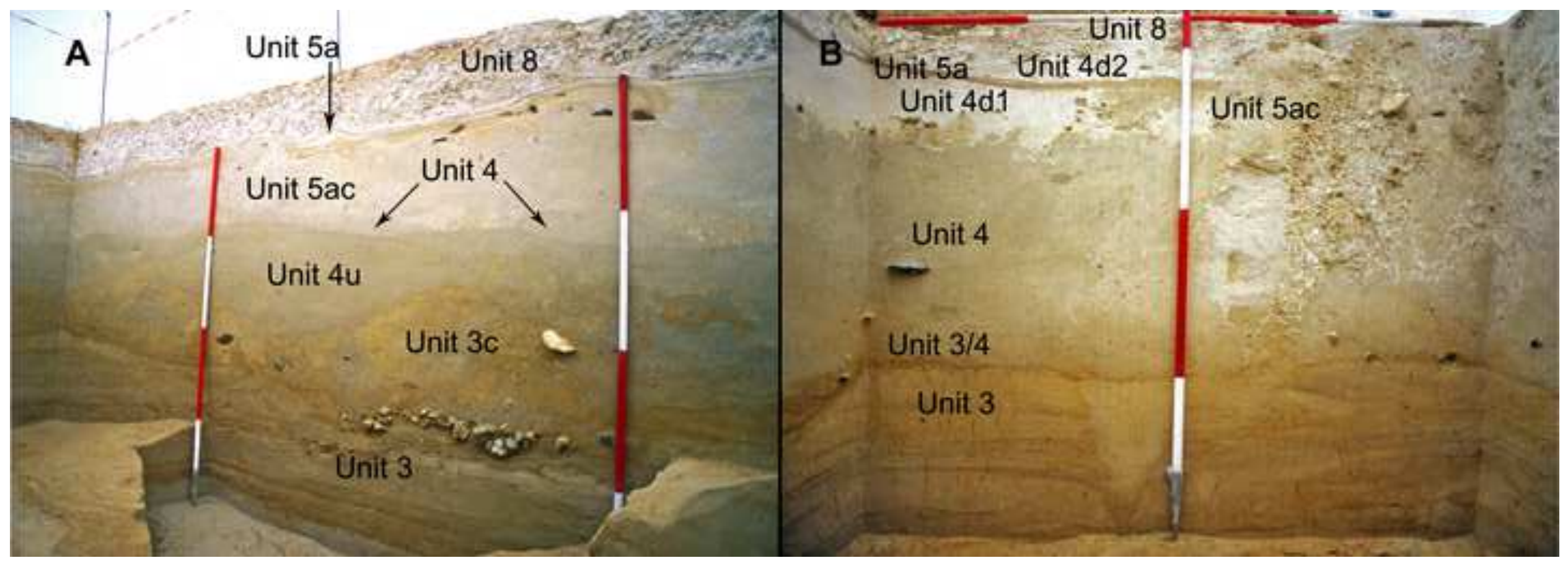




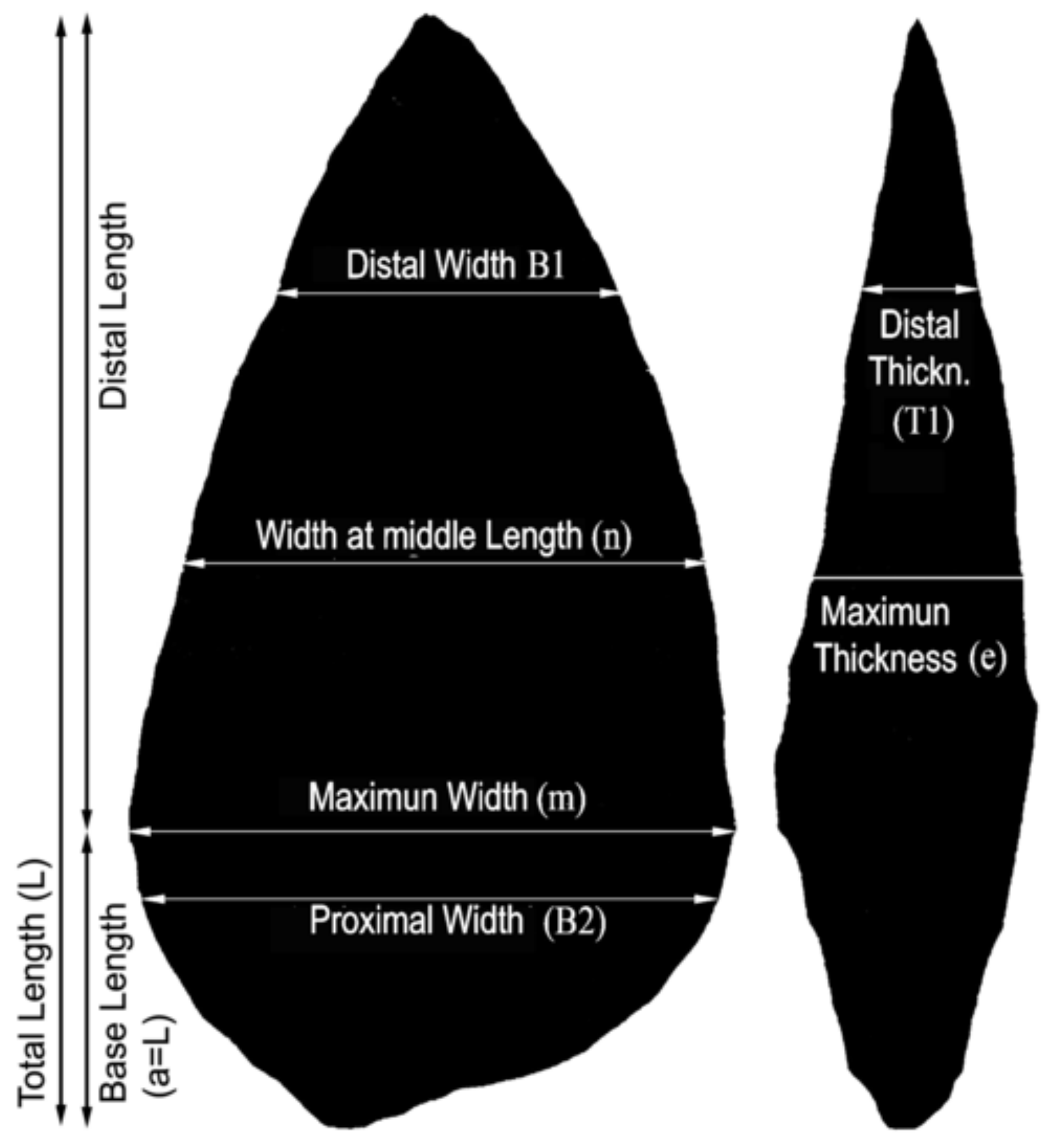

i Elongation: L/m

出 Refinement: m/e

을 Edge Shape:

을 *Bordes (1961): [(L/a)-4.575]* $(\mathrm{n} / \mathrm{m})$

․ ${ }^{*}$ Roe (1968): B1/B2 


\section{oroloporo}

M
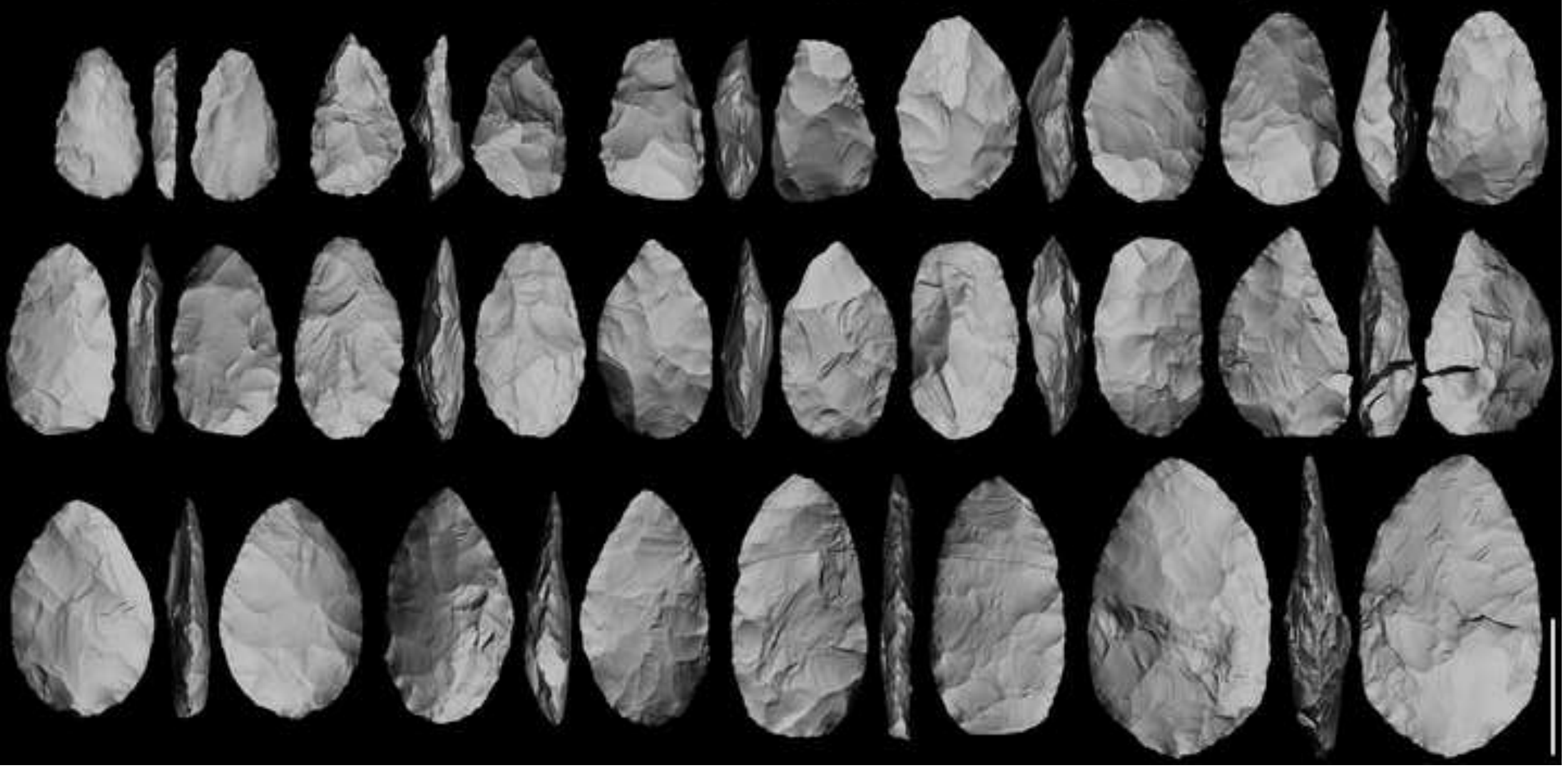


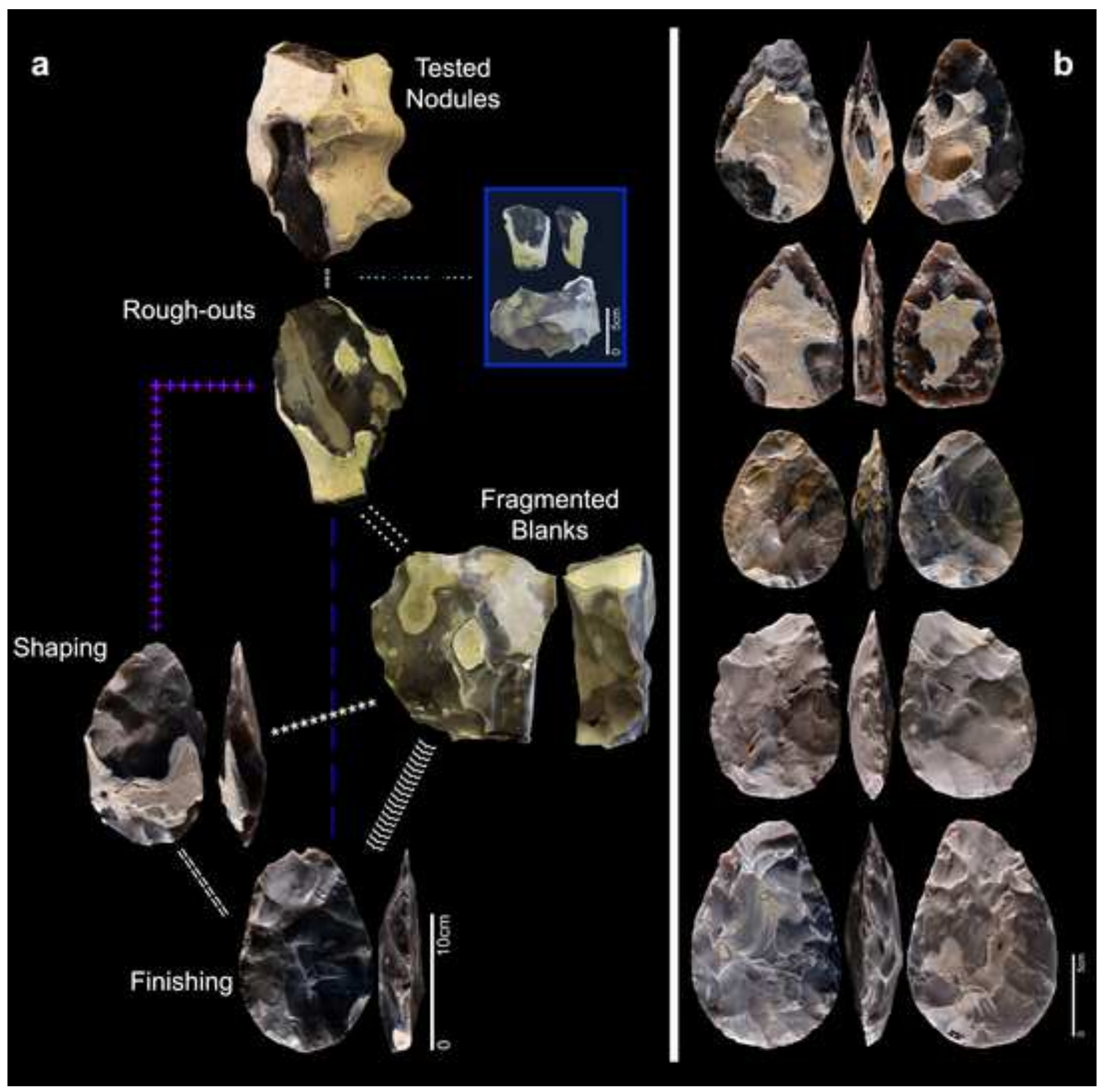



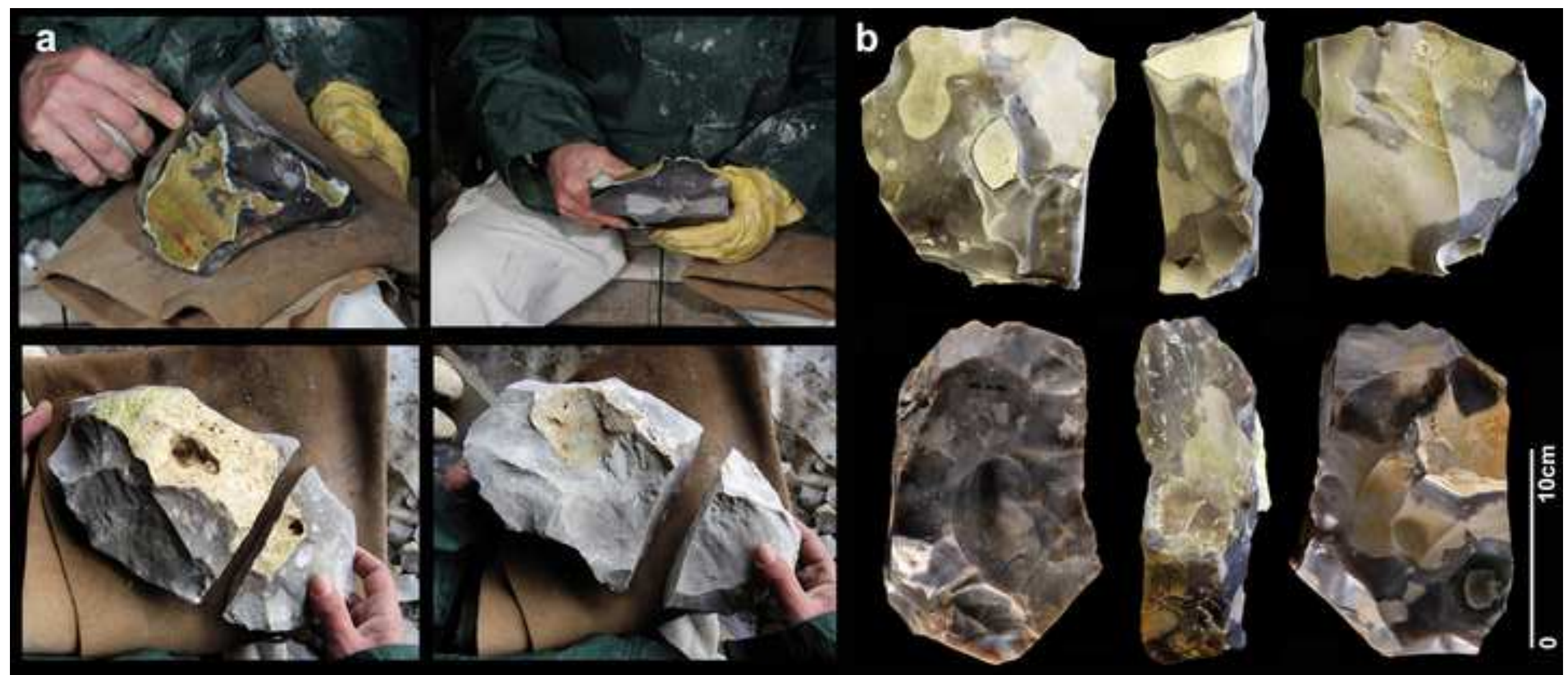


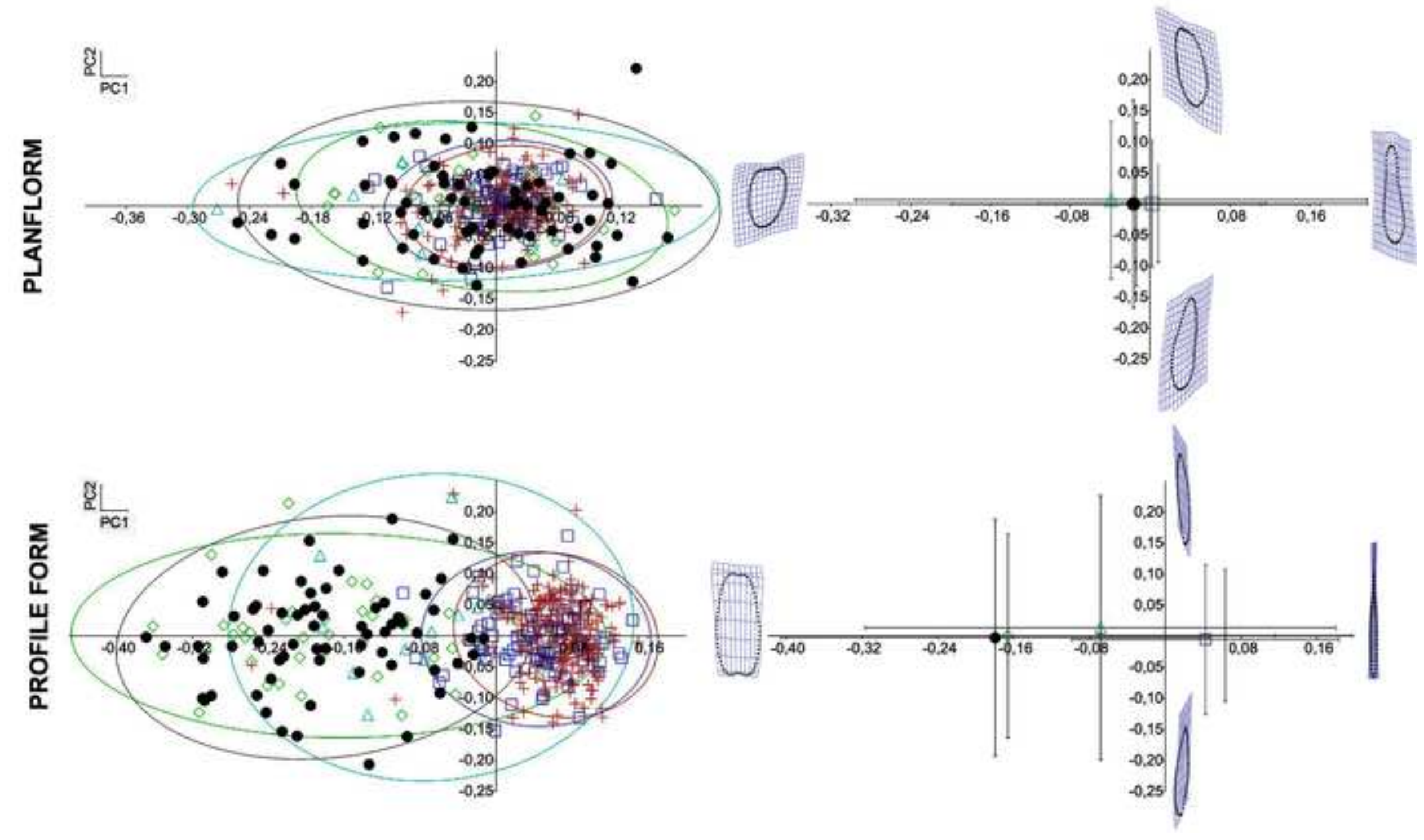



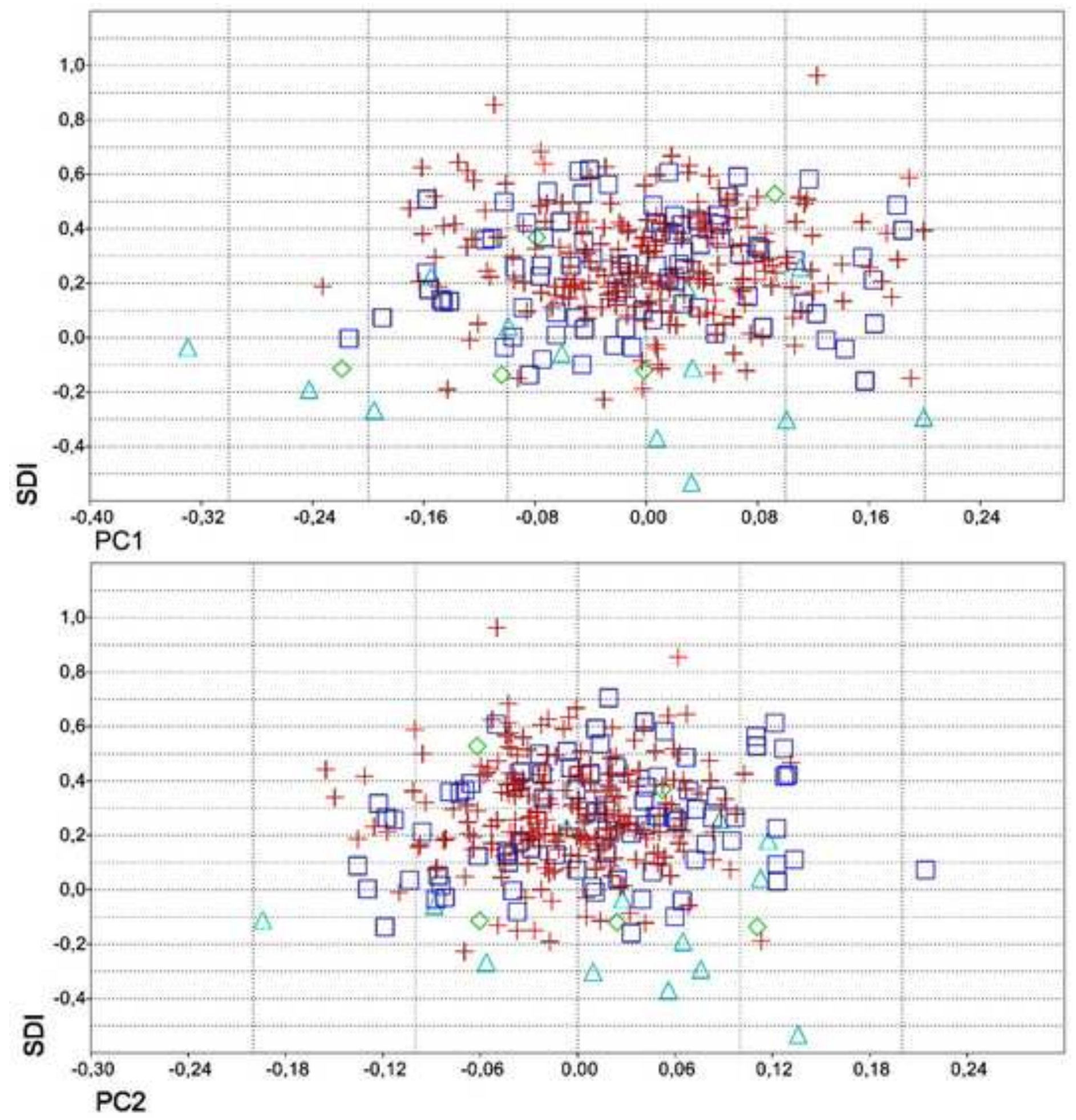


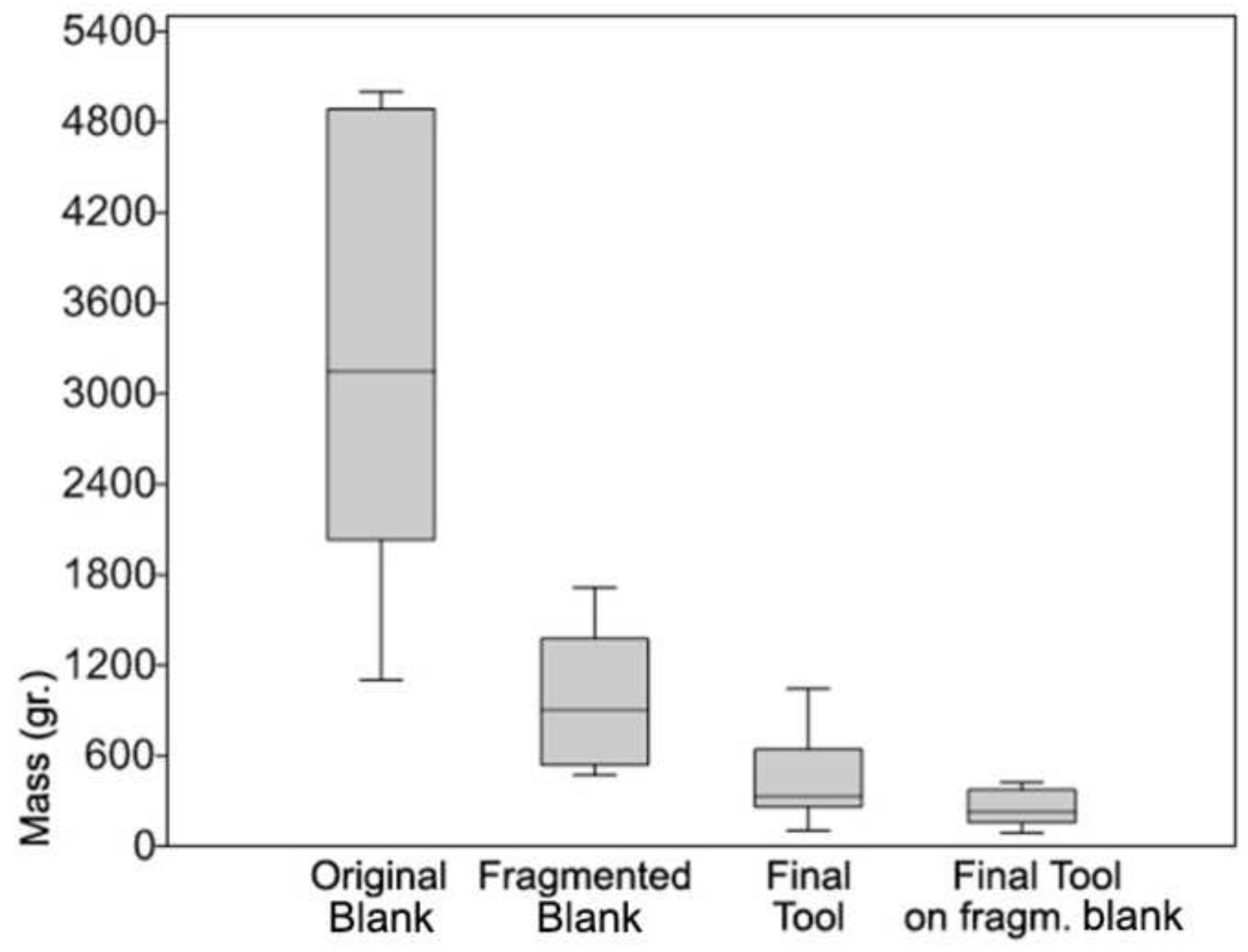



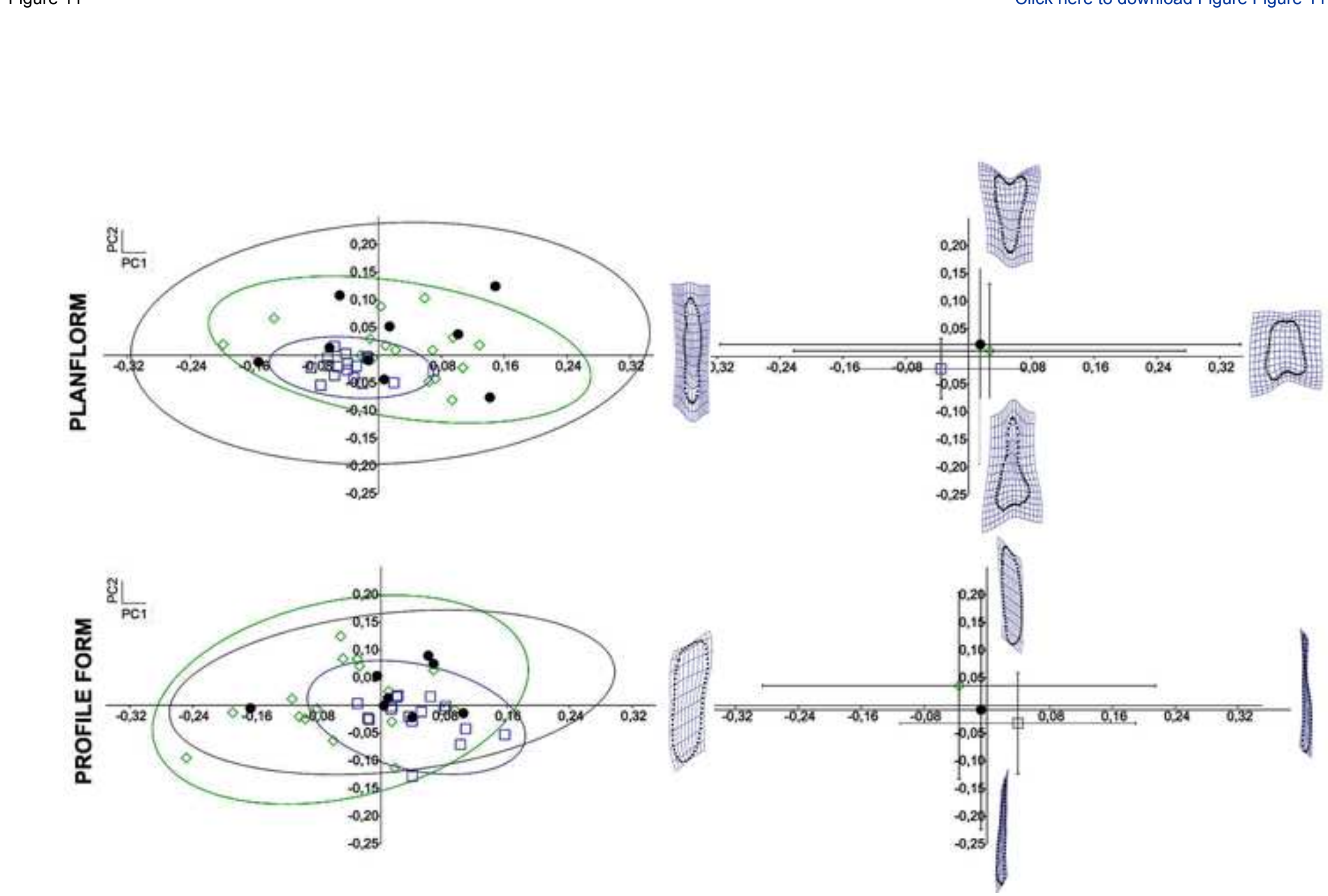


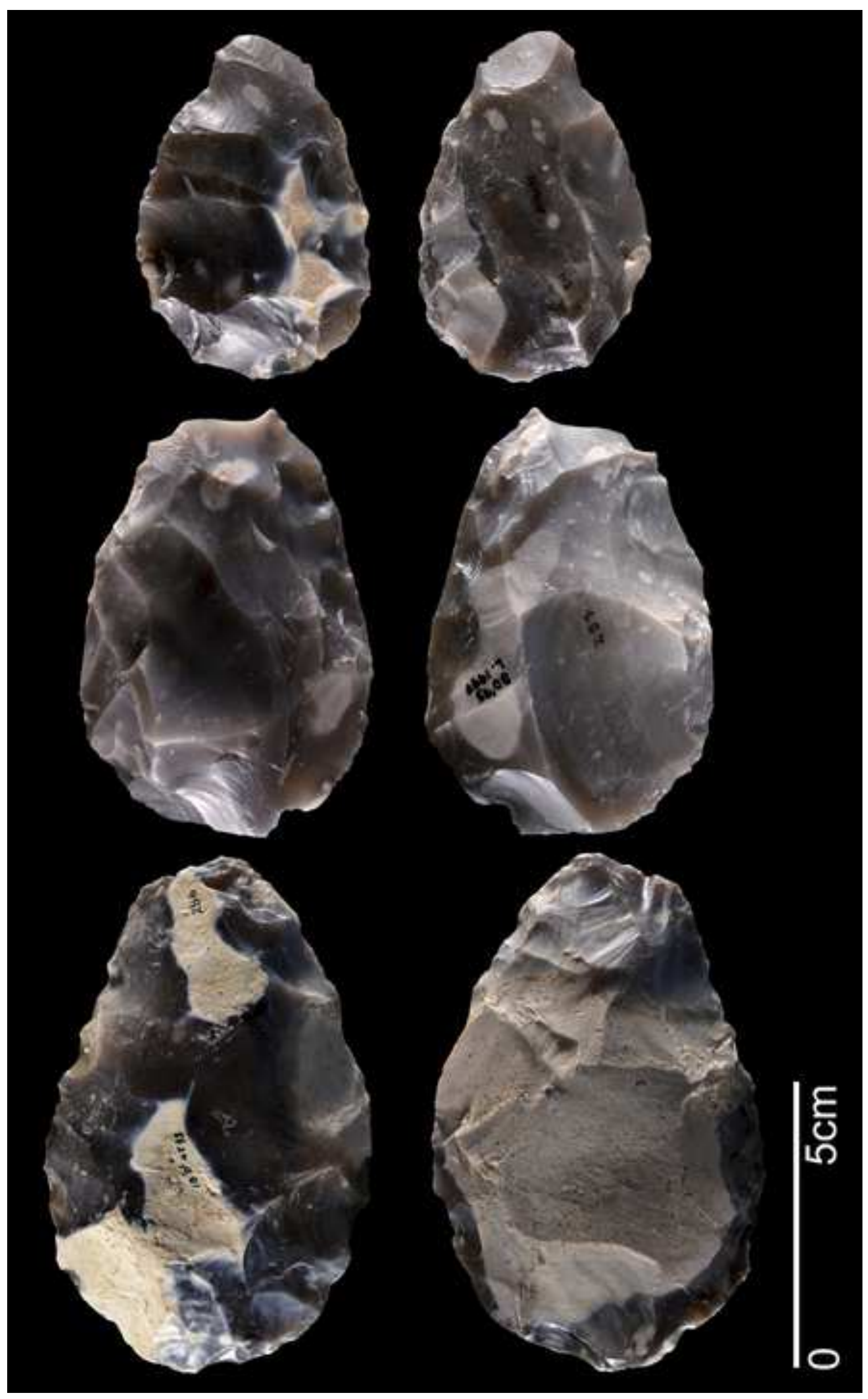




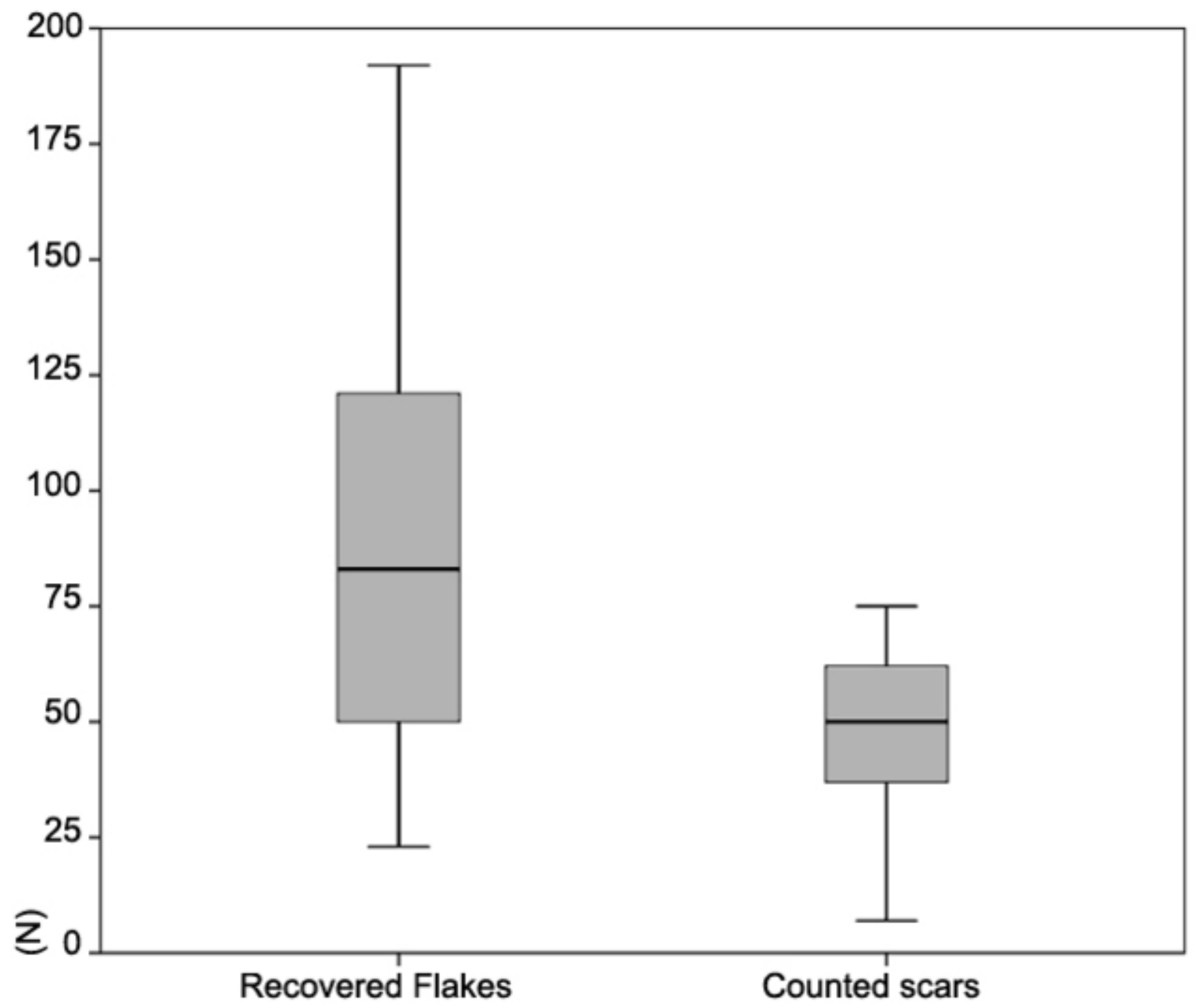




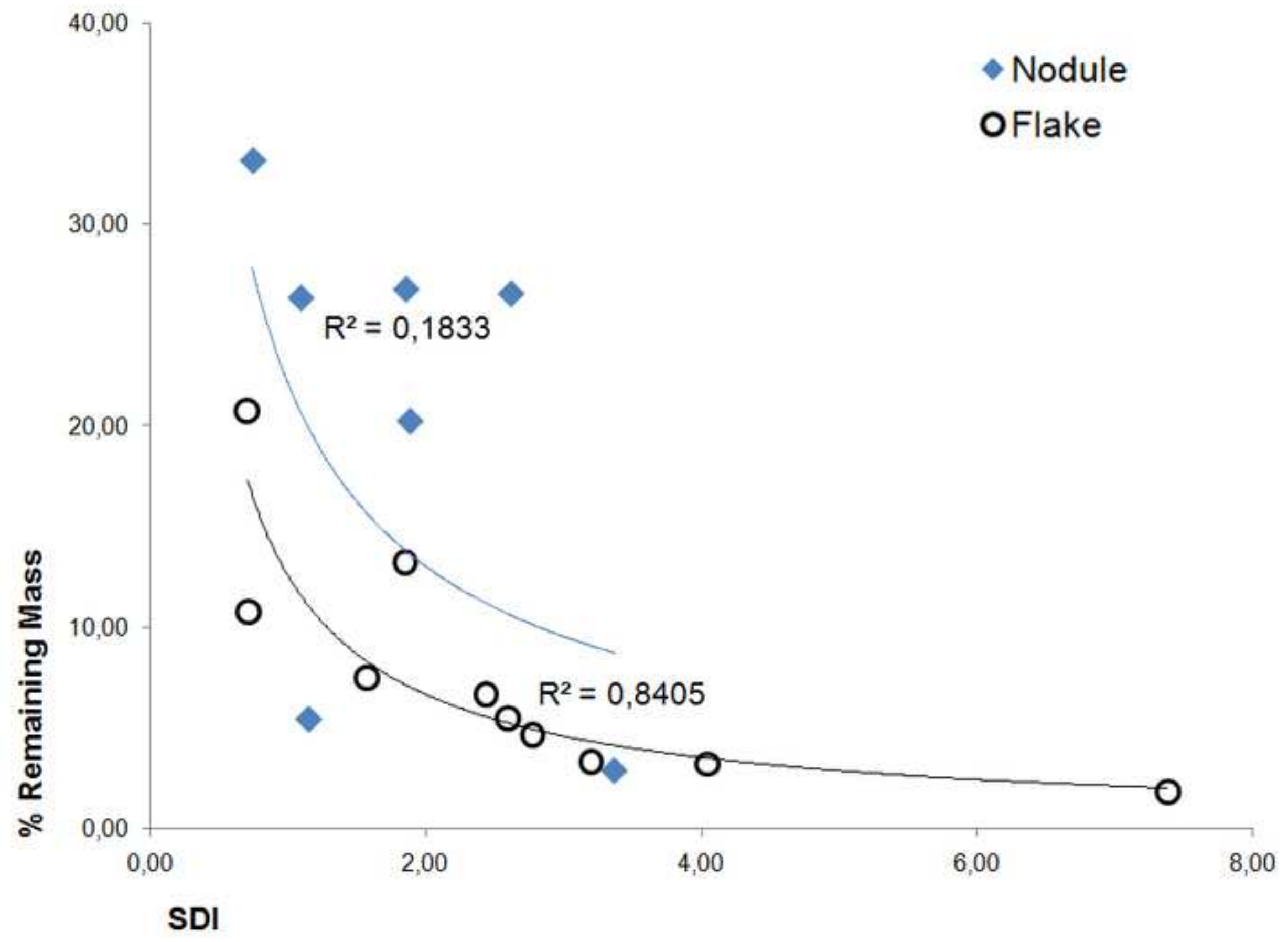



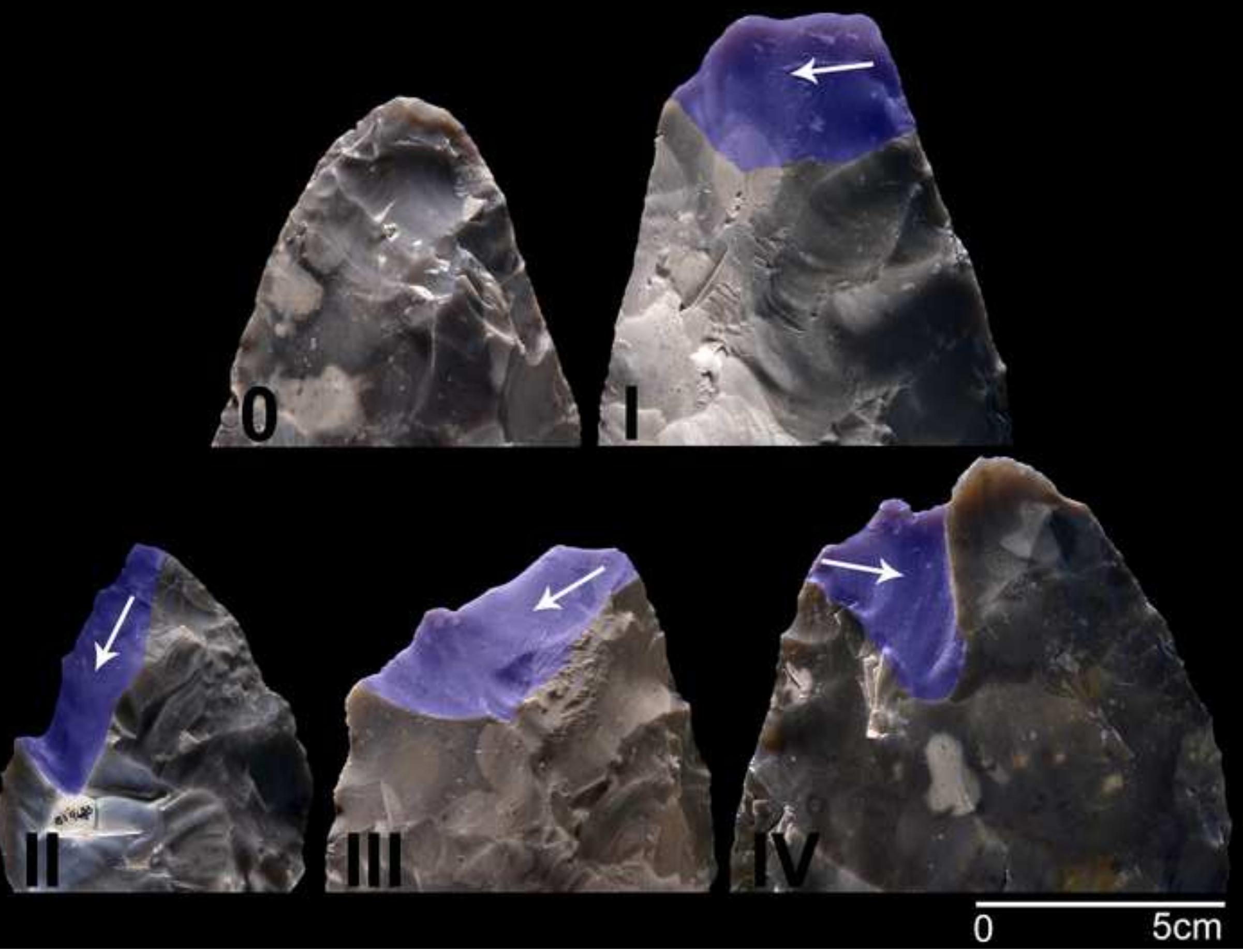


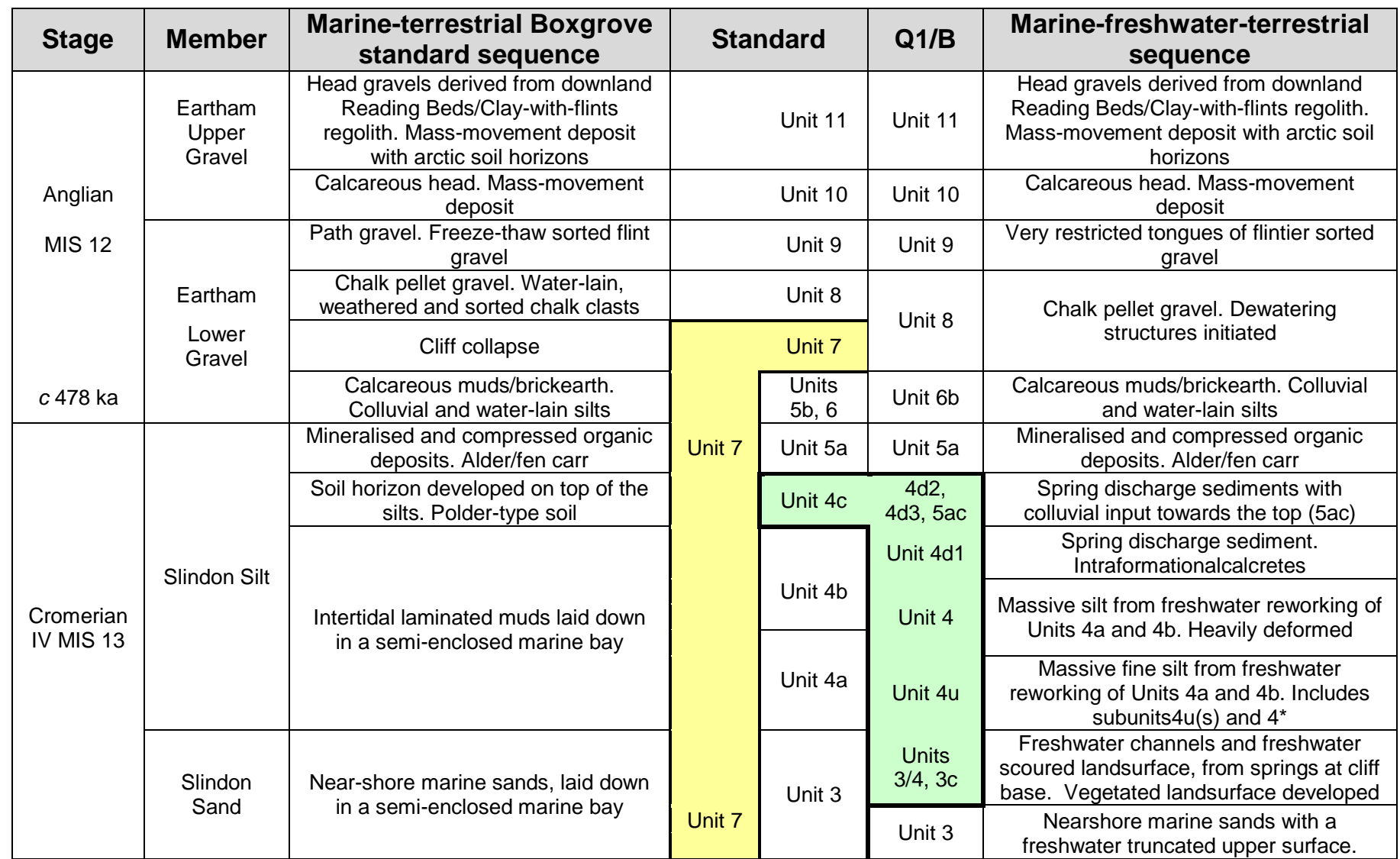




\begin{tabular}{|c|c|c|}
\hline Unit & Description & $\begin{array}{c}\text { Handaxes } \\
\text { (n) }\end{array}$ \\
\hline Unit 3c & Channel cutting through the marine sand of Unit 3 & 27 \\
\hline Unit 3/4 & Landsurface at interface of Units 3 and 4 & 104 \\
\hline Unit 4u & Basal, more clayey, freshwater silt & 87 \\
\hline Unit 4 & Main body of freshwater silt & 220 \\
\hline Unit 5ac & Uppermost bed of the lake, intermixed with terrestrial sediments & 6 \\
\hline Unit 4c & Soil bed formed on surface of marine silt Unit 4b, at lake margins & 3 \\
\hline Unit 5a & $\begin{array}{c}\text { Freshwater organic bed that forms over Unit 4c and the margins } \\
\text { of the lake deposits }\end{array}$ & 5 \\
\hline $\begin{array}{c}\text { Units 6b, } \\
\text { 8a, 8b, PF6 }\end{array}$ & $\begin{array}{c}\text { Terrestrial units above the lake deposits, associated with colluvial } \\
\text { processes and climatic deterioration }\end{array}$ & 7 \\
\hline TOTAL & & $\mathbf{4 5 9}$ \\
\hline
\end{tabular}




\begin{tabular}{|c|c|c|c|c|c|c|c|c|c|c|c|c|c|}
\hline & \multicolumn{4}{|c|}{ Elongation } & \multicolumn{3}{|c|}{ Refinement } & \multicolumn{3}{|c|}{ Bordes' Edge Sh. } & \multicolumn{3}{|c|}{ Roe's Edge Sh. } \\
\hline & $\mathbf{N}$ & Mean & SD & CV & Mean & SD & $\mathrm{CV}$ & Mean & SD & CV & Mean & SD & CV \\
\hline \multicolumn{14}{|c|}{ Boxgrove Q/1B } \\
\hline Test & 76 & 1.48 & 0.36 & 0.24 & 1.44 & 0.33 & 0.23 & - & - & - & - & - & - \\
\hline Rough-out & 46 & 1.49 & 0.29 & 0.19 & 1.65 & 0.41 & 0.24 & - & - & - & - & - & - \\
\hline Frag. blank & 14 & 1.39 & 0.20 & 0.14 & 2.01 & 0.32 & 0.16 & -1.85 & 1.03 & -0.55 & 0.94 & 0.36 & 0.38 \\
\hline Shaping & 88 & 1.51 & 0.16 & 0.10 & 2.65 & 0.54 & 0.20 & -1.81 & 0.85 & -0.46 & 0.81 & 0.11 & 0.13 \\
\hline Finishing & 253 & 1.55 & 0.14 & 0.09 & 2.83 & 0.59 & 0.20 & -1.72 & 0.68 & -0.39 & 0.76 & 0.10 & 0.13 \\
\hline \multicolumn{14}{|c|}{ Experimental Handaxes } \\
\hline Test & 29 & 1.36 & 0.26 & 0.19 & 2.60 & 0.88 & 0.33 & - & - & - & - & - & - \\
\hline Frag. blank & 3 & 1.44 & 0.04 & 0.02 & 2.74 & 0.36 & 0.13 & -1.51 & 0.77 & -0.50 & 0.75 & 0.20 & 0.26 \\
\hline Shaping & 10 & 1.57 & 0.15 & 0.09 & 2.65 & 0.50 & 0.18 & -1.19 & 0.98 & -0.82 & 0.69 & 0.08 & 0.11 \\
\hline Finishing & 8 & 1.73 & 0.12 & 0.06 & 3.20 & 0.89 & 0.27 & -1.36 & 0.88 & -0.64 & 0.74 & 0.07 & 0.09 \\
\hline
\end{tabular}




\begin{tabular}{llcll} 
& \multicolumn{4}{c}{ Experimental Sample } \\
\cline { 2 - 5 } & $\mathbf{N}$ & $\mathbf{F}$ & $\boldsymbol{p}$ & $\mathbf{R}^{\mathbf{2}}$ \\
\hline SDI on scars & $\mathbf{1 7}$ & $\mathbf{S D I}$ & 0.513 \\
SDI on flakes & $\mathbf{1 7}$ & 15.78 & $>0.001$ & 0.340 \\
\hline & \multicolumn{5}{c}{ Type of blank } \\
\hline Nodule & $\mathbf{8}$ & 10.79 & $>0.01$ & 0.683 \\
Flake/Fragment & $\mathbf{1 0}$ & 10.47 & $>0.01$ & 0.567 \\
\hline
\end{tabular}




\begin{tabular}{rc|ccc|ccc}
\cline { 2 - 7 } & $\mathbf{N}$ & $\mathbf{F}$ & $\mathbf{p}$ & $\mathbf{r}^{\mathbf{2}}$ & $\mathbf{F}$ & $\mathbf{p}$ & $\mathbf{r}^{\mathbf{2}}$ \\
\cline { 2 - 7 } Test & 8 & 0,480 & 0,514 & 0,074 & 7,622 & 0,032 & 0,559 \\
Rough-out & 5 & 2,466 & 0,214 & 0,451 & 0,511 & 0,526 & 0,145 \\
Fragm. Blank & 13 & 0,026 & 0,874 & 0,002 & 0,133 & 0,721 & 0,012 \\
Shaping & 84 & 1,266 & 0,263 & 0,015 & 3,347 & 0,701 & 0,039 \\
Finishing & 235 & 1,053 & 0,305 & 0,004 & 0,017 & 0,895 & $<0,001$ \\
\hline
\end{tabular}

